The Royal College of Psychiatrists'

Journal of Continuing

Professional Development

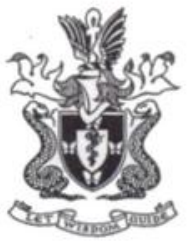

Advances in Psychiatric Treatment

Editor: Andrew Sims, Director of Continuing Professional Development

\section{Contents of the January 1996 issue}

Management of the sexually abused child. D. P. H. Jones

What managers should expect of consultant psychiatrists. L. Joyce, R. Perkin Environmental quality for patients with dementia. P. Bowie

Electroconvulsive therapy machines. C. Robertson, G. Ferguson

Cognitive behaviour therapy for whom? S. Moorey

Risk assessment. "A word to the wise?". M. Vinestock

Subscription rate for Volume 2, 1996

(6 issues starting January 1996):

Europe, including UK $£ 50.00$

USA US\$80.00 Elsewhere $£ 60.00$

Full airmail $£ 6 / \$ 10$ extra

To enter your subscription or to obtain a sample copy of APT, contact:

Publications Subscription Department, Royal Society of Medicine Press Limited,

PO Box 9002, London W1M 0ZA, UK. Tel: (+44) 0171290 2927/8; Fax: (+44) 01712902929
Epilim Oral Prescribing Information

Presentation Epilum 2011 Enteric Couted and Epilm 501 Enteric Coated: Enteric coated tablets containng 2(K/mg, and $5(1) \mathrm{mg}$ Sodium Valproate Ph.Fur. reppectively. Epilim Cruhable Tablet contanning $100 \mathrm{mg}$ Sodium Valproate Ph.Eur. Epilm Svrup and Fpilim Liyund (sugar free) both contuning $2011 \mathrm{mg}$ Sodium Vilproste Ph.Fur. per 5ml. Epilim Chrono 260. Fpilim Chrono 36k) and Eplim Chrono 500: Controlled release tablets containng a mixture of Sodum Valproate Ph. Eur. and Valprose Acid Fr.P. cqunalcont to $210 \mathrm{mg}$. $300 \mathrm{mg}$, and $5(\mathrm{k} / \mathrm{mg}$ Sodium Valproste respectively. Indications ()ral formulations of Epilim are indicated for all eppes of eptlepey. In women of child bearing age Epilim should be used only in severe cases or in those resistant to other treatment. Dosage and administration Adults; the dowe hould be titrated at three dis interval until werure

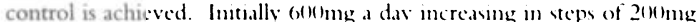

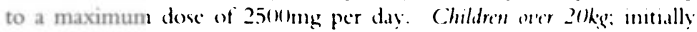
$400 \mathrm{mg}$ a day increasing in stepe to a maximum does of $35 \mathrm{mg} / \mathrm{kg} / \mathrm{day}$ Children under 20kg: intially $20 \mathrm{mg} / \mathrm{kg} / \mathrm{day}$ - the done max be increased in steps to a maximum of $+11 \mathrm{mg} / \mathrm{kg} / \mathrm{d}$.ay provided that plawma level are monitored. Epilum (hrono may be given once or whe daly. All other formulations hould be given ewice daty. Combmathen theraply levels of Epilim and co-rdmmsered anticonvulsums mas be atfected and optimum dowge 1 determuned by izure control. Contraindications, Warnings, etc. Contrandliatlens Active liver

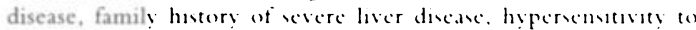
valproate. Side effect Impared hepatie function. partscularty in children, occassonally kending to hepatse tulure - treatment should be withdrawn in patient who suddenly develop smptoms computuble

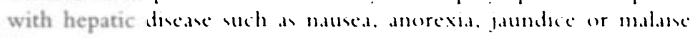
Hyperammonacmia with or without hepatic dysuncton. Blood dyscrasia - impared platelet function, thrombectopenta, occasonal leucopenia and red cell hypoplasu. ()castonally increand appetute. weight gain, transient hair low, behavioural disturbances, alterations to the menstrual avele and pancreatitis. Simptom of intoxication include ataxia, tremor, and tupor. Intg inferathons Eplim has ignificant interactions with phenvtoin, limotrigine and other antrounvulsunts Epilim may potenteate the effects of neuroleptios. MA()h, and other antidepressants, anticoagulants and silicylates. (imetidine mix inhibit the metabolism of Epilim. Epilim has no effect on the efficacy of oral contraceptives. Pregnancy An increased incidence of congenital abnormalities las been demonstroted in offiprung born to mothers with epilepsy both untreated and treated. including thone treated with sodium valproate. Neural tube defects have been reported in about 1 ". of offspring of women who hase recested salpreste durng the firt trimester of pregnancy. P'regnance should be sereoned for neural tube defects by estimation of alphateteprotein and ultrasound. Folate supplementation has becen bown we reduce the medence of neursl tube defects in the offiprng of high rok women. Legal category

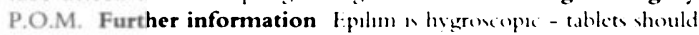
not be removed from their foil until thes are uned. Fpilm (hromo in recommended in case where plama valproate level are being measured on account of it pharmacokinctas. The effective

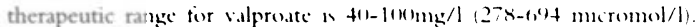
Product Licence Numbers Epulum 2111 Enteric Costed 11723/(1)18.

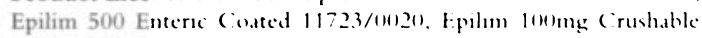
Tablets 1172.3/16177. Fpilim Sirup 11723/10625. Epilim Liyusd 11723/0024, Ephlim (hrono 200 11723/(1678. Fpulum (hrono 36u) 11723/0021, Epilm (hrono $510111723 / 101,-9$. NHS Cost Epilum

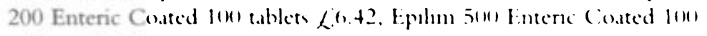

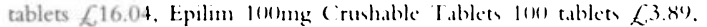
Epilim Syrup $300 \mathrm{ml}$ 2.5.89. Fpilim Liquat 3016ml 6.5 .89 . Epilim

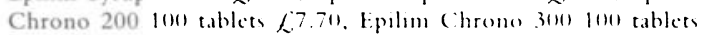
C11.55, Epilim (hrono 5(1) low tablet /19.25. Address: Sanofi Winthrop Ltd., ()ne ()nslow Strect, (iutlfiord. Surrey (iU1 tYS Telephone: $(11+8.3) \quad 5115515$ Fax: $(11+8.3) \quad 35+32$. Epilm. Epilim Chrono and the Chrono device are registered trade marks. Date of preparation August 1905

\section{References:}

1. Chadwick 1).. I. Niurol .Neurours Psychiatry 1994: 57: 204-277.

2. Gilham R.A.. Lipilepsy Res., 1990: 7: $219-225$. sanofi

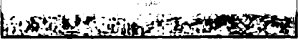




\section{THE BRITISH JOURNAL OF PSYCHIATRY}

INDEX TO VOLUME 167

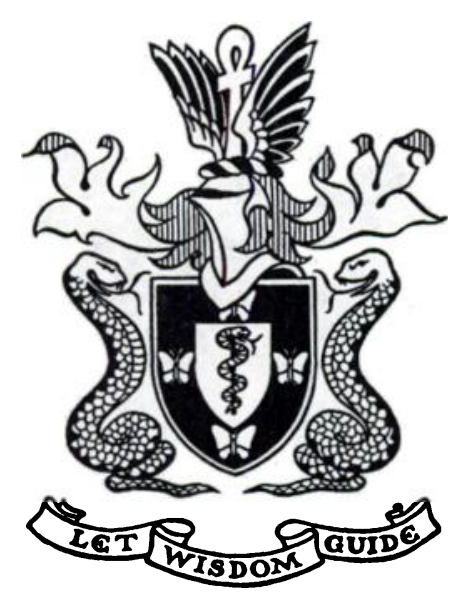

\section{JULY - DECEMBER 1995}

(C) The Royal College of Psychiatrists 


\title{
Index to Volume 167
}

\section{Compiled by Linda English}

\author{
PART I - SUBJECTS \\ $3-13$ \\ PART II - CONTRIBUTORS 13-20 \\ PART III - BOOK REVIEWS \& BJP REVIEW OF BOOKS $20-23$
}

Abbreviations: C, Correspondence; R of B, BJP Review of Books; suppl., supplement.

\section{PARTI.SUBJECTS}

\section{Abnormal Involuntary Movement Scale}

Lipid peroxide and vitamin $\mathrm{E}$ in tardive dyskinesia. Robin $\mathrm{G}$. McCreadieet al 610-617

Tardive dyskinesia in schizophrenia. John L. Waddingtonet al $41-44$

Admission beds. Crisis. Four-year survey of the bed-state of Greater London's acute psychiatric units. Robin B. Powellet al 765-769

Admission rates. Social deprivation and rates among different diagnostic groups. Judy Harrison et al 456-462

Adolescence

Family functioning in anorexia nervosa. Clive North et al 673-678

Periodic psychosis of puberty revisited. Kazuhiko Abe and Mikio Ohta 507-513

see also Childhood and adolescence

Adversity. Women's response. G. C. Mezey (C) 266

Affective psychoses. Somatic delusions. Iain McGilchrist and John Cutting 350-361

Afro-Caribbeans. Second-generation in Britain. Child and adolescent psychiatric presentations. Robert Goodman and Hilary Richards 362-369

Age-associated memory impairment. Prevalence study. Andrew Barkeret al 642-648

Agoraphobia. Panic disorder. Cognitive behaviour therapy with buspirone or placebo. Jean Cottraux et al 635-641

A hundred years ago. Henry Rollin

Alleged increase of insanity 826

Association of Workers in Asylums for the Insane. By Fletcher Beach 554

Malingering and miracles 700

New Inebriates Bill 270

Simulation of death by fakirs 119

Society for the Study of Inebriety 414

Akathisia. Neuroleptic-induced. Cyproheptadine treatment. David Weiss et al 483-486

Alcohol misuse

Gender differences in parental psychology following infant death. John C. Vance et al 806-811

Morbid jealousy. Albert Michael et al 668-672

New Inebriates Bill. Henry Rollin (A hundred years ago) 270

Psychosocial outcome of liver transplant. L. M. Howard and T. Fahy (C) 267-268
Society for the Study of Inebriety. Henry Rollin ( $A$ hundred years ago) 414

Alpha2 adrenoceptor. Clozapine-induced hypersalivation. F. M. Corrigan et al (C) 412

Alzheimer's disease

Apolipoprotein E genotype and its effect on duration and severity of early and late onset disease. Jennie Norrman et al 533-536

Further evidence that reading ability is not preserved. R. E. O'Carrollet al 659-662

Normal ageing. Brain atrophy. Hans Förstl et al 739-746

Presenile. Community care. M. Evans (C) 408

Presenile. Epidemiology in Scotland (1974 to 1988). Lawrence $\mathrm{J}$. Whalley et al

I. Non-random geographical variation 728-731

II. Exposures to possible risk factors $732-738$

Validation of a French version of an informant-based questionnaire as a screening test. Samuel Law and Christina Wolfson 541-544

Analyses see Statistics

Anorexia nervosa

Family functioning in adolescence. Clive Northet al $673-678$

'Non-white' populations. G. M. Soomroet al 385-389

Anticoagulated state. Intramuscular injections. P. Aitken and J. Bolton (C) 269

Antidepressants

Behavioural toxicities. J. S. Kerret al (C) 413. J. F. O'Hanlon and H. Freeman (Authors' reply) (C) 413-414

Economics of treatment of depression. D. W. Owens (C) 112. B. Jönsson and P. E. Bebbington (Authors'reply)(C) 112. C. Thompson (C) 112

Effect of exposure to dothiepin and northiaden in breast milk on child development. Anne Buist and Helen Janson 370373

In pregnancy and breastfeeding. D. A. Ratan and T. Friedman (C) 824

Repeat prescriptions and residential care. A. Farmer(C) 408409

SSRIs and tricyclics in combination. David Taylor (Review Article) 575-580

see also individual names

Antipsychotics

Drug-induced dysphoria. D. J. King et al 480-482

Lead-in placebo washout period. J. Volavka (C) 694

see also Neuroleptics and individual names 


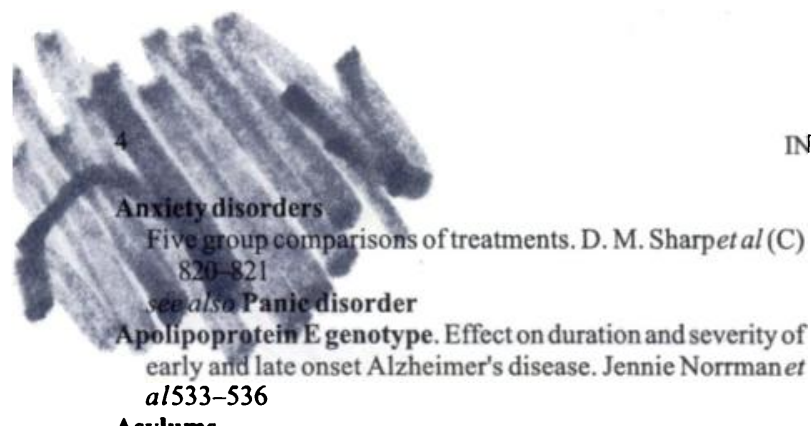

Asylums

Association of Workers in Asylums for the Insane. By Fletcher Beach. Henry Rollin (A hundred years ago) 554 see also Leros PIKPA

Auditory hallucinations. Chronic. Exposure control in schizophrenia. Rajendra Persaud and Isaac Marks 45-50

Behavioural family management. Immigrant families coping with schizophrenia. Cynthia Telles et al 473-479

Behavioural toxicities. Antidepressants. J.S. Kerret al (C) 413. J. F. O'Hanlon and H. Freeman (Authors' reply)(C) 413-414

Behaviour symptoms. Severely and profoundly mentally retarded patients. Andrew H. Reid and Brian R. Ballinger $452-455$

Bereavement. Gender differences in parental psychology following infant death. John C. Vance et al 806-811

Biological psychiatry. Reductionism. Hasse Karlsson and Matti Kamppinen (Editorial) 434-438

Bipolar disorder

Is there a seasonal pattern of relapse? Trevor Silverstone et al 58-60

Psychotherapy. Jan Scott (Review Article) 581-588 see also Manic-depression

Blu-Tack. A novel subtance of abuse. M. Walker-Kinnear and T. Jones (C) 550-551

Bovril. Moclobemide. Treatment of clozapine-induced hypotension. D. Taylor et al (C) $409-410$

Brain

Atrophy in normal ageing and Alzheimer's disease. Hans Förstl et al 739-746

Brains, biases, deficits and disorders. Richard P. Bentall (Commentary) 153-155

Damage and tardive dyskinesia. A. Al-Adwani(C) 410-411

Darwinian approach to the origins of psychosis. T. J. Crow (Review Article) 12-25

MRI and SPET and treatment response in schizophrenia. Stephen M. Lawrie et al 202-210

Neuropsychiatric sequelae of mercury poisoning. R. E. O'Carrollet al 95-98

Neuropsychological slowness in OCD. Silvana Galderisiet al 394-398

Perfusion abnormalities in Tourette's syndrome. John Moriarty et al 249-254

Post-concussional state: neurophysiological aspects. M. R. Watson et al 514-521

Psychosurgery for obsessional disorder. R. P. Snaith et al (C) 411

Regional activity in chronic schizophrenic patients during a verbal fluency task. C. D. Frith et al 343-349

Regional cerebral blood flow in OCD patients at rest. James V. Luceyet al 629-634

Sensorimotor cortex and supplementary motor area changes in schizophrenia. J. Schröder et al 197-201

Tardive dyskinesia in schizophrenia. Relationship to minor physical anomalies, frontal lobe dysfunction and cerebral structure on MRI. John L. Waddington et al 41-44

\section{Breastfeeding}

Effect of exposure to dothiepin and northiaden on child development. Anne Buist and Helen Janson 370-373

Pregnancy. Antidepressants. D. A. Ratan and T. Friedman (C) 824

\section{Brief Psychiatric Rating Scale}

Clozapine in neuroleptic-resistant schizophrenia. Moshe Avnon and Jonathan Rabinowitz 760-764

Schizophrenia and expressed emotion in Japan. Shuichi Tanaka et al 794-798

Britain

Child and adolescent psychiatric presentations of secondgeneration Afro-Caribbeans. Robert Goodman and Hilary Richards 362-369

see also London and Scotland

British Journal of Psychiatry

Behavioural toxicities of antidepressants. J. S. Kerr et al (C) 413. J. F. O'Hanlon and H. Freeman (Authors' reply) (C) 413-414

Structured abstracts. D. J. Castle (C) 266-267

Use of statistics. S. M. McGuigan 683-688. Improving the quality of statistics in psychiatric research. David Hand and Pak Sham (Commentary) 689-691

Bulimia nervosa. Significance of a history of childhood sexual abuse. Patrick F. Sullivan et al 679-682

Burns' Symptom Checklist. Associations of psychotic symptoms in dementia sufferers. Clive Ballardet al 537-540

Buspirone. With cognitive behaviour therapy in panic disorder with agoraphobia. Jean Cottraux et al 635-641

Camberwell Assessment of Need. Validity and reliability of an instrument to assess the needs of people with severe mental illness. Michael Phelan et al 589-595

Camberwell Family Interview. Schizophrenia and expressed emotion in Japan. Shuichi Tanaka et al 794-798

Cambridge Project for Later Life. Subtypes of dementia in the elderly. C. Brayneet al 255-262

Carbamazepine. Mania precipitated by withdrawal. D. A. Scull and M. R. Trimble (C) 698

Case reports. Confidentiality. I. G. Bronks (C) 552-553. B. Dimond (Author's reply)(C) 553-554

Charles Bonnet syndrome. D. K. Arya (C) 114-115. A. Fernandez and G. Lichtshein (C) 115

Childhood

Effect of exposure to dothiepin and northiaden in breast milk on development. Anne Buist and Helen Janson 370-373 Institutions. I. Kolvin (Editorial) 8-11

Lone mothers and their children. Jane Roberts (Editorial) 159-162

Significance of a history of childhood sexual abuse in bulimia nervosa. Patrick F. Sullivanet al 679-682 see also Leros PIKPA Asylum

Childhood and adolescence

Psychiatric presentations of second-generation AfroCaribbeans in Britain. Robert Goodman and Hilary Richards 362-369

Young offenders, serious crimes. Susan Bailey (Editorial) 5-7

see also Adolescence 
China

Classification of mental disorders. Sing Lee (C) 117-118

Population policy and eugenics. Veronica Pearson (Editorial) 1-4. L. Uzych(C) 697-698

Chronic fatigue syndrome

Cognitive functioning and MRI. Helen Copeet al 86-94. E. M. Goudsmit and S. Howes (C) 818. H. Cope and A. David (Authors'reply)(C) 818-819

Neurasthenia revisited: ICD-10 and DSM-IV psychiatric syndromes in patients. Anne Farmer et al 503-506

T.Chalder(C) 549-550. M. F. Shanks(Author's reply)(C) 550

Classification. Chinese classification of mental disorders. Sing Lee(C) 117-118

Clinician-Administered PTSD Scale(CAPS). Medium-term course of disaster victims. C. Duggan and J. Gunn 228-232 Clozapine

Effectiveness in hospitalised people with chronic neuroleptic-resistant schizophrenia. Moshe Avnon and Jonathan Rabinowitz 760-764

Induced hypersalivation and the alpha2 adrenoceptor. F. M. Corriganet al (C) 412

Induced hypotension treated with moclobemide and Bovril. D. Tayloret al (C) 409-410

Obstacles to innovation in a peripheral hospital. Michael Launer (Editorial) 431-433

Risperidone response after no response. M. Avnon and A. Kunin(C) 699

Cognitive-behavioural therapy

Five group comparisons of treatments for anxiety disorders. D. M. Sharpet al (C) 820-821

Lithium therapy. Long-term effects on depression in the elderly. K. C. M. Wilsonet al 653-658

With buspirone in panic disorder with agoraphobia. Jean Cottrauxet al 635-641

Cognitive functioning. MRI. Chronic fatigue. Helen Copeet al 86-94. E. M. Goudsmit and S. Howes (C)818. H. Cope and A. David (Authors' reply)(C) 818-819

Cognitive neuropsychiatry. Future of diagnosis: ' $\mathrm{PC}$ ' model of the mind. Bruce G. Charlton (Editorial) 149-153. Brains, biases, deficits and disorders. Richard P. Bentall (Commentary) 153-155. Future of diagnosis. Anthony David (Commentary) 155-157. Method in madness. John C. Marshall and Peter W. Halligan (Commentary) 157-158. P.J. Harrison and J. Geddes (C) 692. D. Hartman (C) 693. F. Oyebode (C) 693-694

Community care

Keeping count for the community. M. Blackwell (C) 823

People with treated long-term mental illness. Greg Wilkinson et al 26-37. Ian Pullen and Tony Kendrick (Comment) 3840

Presenile Alzheimer's disease. M. Evans (C) 408

Statistical design, analysis and further correspondence. I. Marks (C) 270

Community psychiatric nurse teams. Costs. T. Burns (C) 268 P. McCrone et al (Authors' reply) (C) 268-269

Computers. See Cognitive neuropsychiatry

Confidentiality. Case reports. I. G. Bronks (C) 552-553. B. Dimond (Author's reply)(C) 553-554

Consent. Informed consent in chronic schizophrenia? Gareth H. Jones (Editorial) 565-568
Costs

Community psychiatric nurse teams. T. Burns (C) 268. P. McCrone et al (Authors' reply) (C) 268-269

Economics of treatment of depression. D. W. Owens(C) 112. B. Jönsson and P. E. Bebbington (Authors' reply)(C) 112. C. Thompson (C) 112

Psychotropic medication. F. Johnstone et al (C) 112-113

Cultures. Context of hallucinations. F. Klemperer(C) 115-116

Cyproheptadine. Treatment of neuroleptic-induced akathisia. David Weiss et al 483-486

Deinstitutionalisation. Rehabilitation. Intervention project. Leros PIKPA Asylum. J. Tsiantis et al (suppl. 28) 10-45

Delusions. Somatic. Schizophrenia and the affective psychoses. Iain McGilchrist and John Cutting 350-361

Dementia

Associated psychiatric symptoms in older people with learning disability. Steve Moss and Pradip Patel 663-667

Associations of psychotic symptoms in sufferers. Clive Ballardet al 537-540

Incidence of clinically diagnosed subtypes in an elderly population. C. Brayne et al 255-262

Lewy body dementia - diagnosis and treatment. Ian G. McKeith et al (Editorial) 709-717

Life events. M. Mobayed and D. Baynes (C) 407-408

see also Alzheimer's disease

Depression

Aetiology

Later life. Comparison of symptoms and risk factors in early and late onset cases. R. C. Baldwin and Barbara Tomenson 649-652

Sexual abuse in patients with eating disorder, depression and normal controls. Christine M. Vize and Peter J. Cooper 80-85

Complications

Edinburgh Primary Care Study. Personality disorder and outcome. Douglas A. Patience et al 324-330

Late-life depressive disorder. M. Lester and M. Blanchard (C) 822. R. L. van Ojen and W. van Tilburg (Authors' reply)(C) 822-823

Psychotic and depressive symptoms in Parkinson's disease. John D. C. Mellers et al 522-526

Delusions. Somatic delusions in the affective psychoses. Iain McGilchrist and John Cutting 350-361

Epidemiology. Prevalence and correlates in a population of nonagenarians. Y. Forsell et al $61-64$

Outcome

Edinburgh Primary Care Study. Personality disorder and outcome. Douglas A. Patience et al 324-330

Fifteen to twenty year follow-up of adult psychiatric patients. David Quinton et al 315-323

Therapy

Economics of treatment. D. W.Owens(C) 112. B. Jönsson and P. E. Bebbington (Authors' reply) (C) 112. C. Thompson(C) 112

Effect of valine on mood in remitted patients. D. J. Williamsonet al 238-242

Long-term effects of cognitive-behavioural therapy and lithium therapy in the elderly. K.C.M. Wilsonet al653658 
Psychological treatments. Jan Scott (Editorial) 289-292 see also Antidepressants

Developing countries. Delineation of acute and transient psychotic disorders. Ezra Susser et al 216-219

Diagnoses

Cognitive neuropsychiatry and the future of diagnosis: 'PC' model of the mind. Bruce G. Charlton (Editorial) 149-153. Brains, biases, deficits and disorders. Richard P. Bentall (Commentary) 153-155. Future of diagnosis. Anthony David (Commentary) 155-157. Method in madness. John C. Marshall and Peter W. Halligan (Commentary) 157158. P. J. Harrison and J. Geddes (C)692. D. Hartman (C) 693. F. Oyebode (C) 693-694

Lewy body dementia - diagnosis and treatment. Ian G. McKeith et al (Editorial) 709-717

Social deprivation and psychiatric admission rates among different diagnostic groups. Judy Harrisonet al 456-462 Disasters

At sea. Psychological effects. E. Dooley and J. Gunn 233237

Medium-term course of victims. C. Duggan and J. Gunn 228232

Psychological consequences of Kegworth air disaster. W. Gregget al 812-817

Dothiepin. Northiaden. Effect of exposure in breast milk on child development. Anne Buist and Helen Janson 370-373

Down's syndrome. Cardiovascular and autonomic functionprescribing implications. P.K. Carpenter(C) 118-119

Drug misuse see Alcohol and Substance misuse

Drugs

Cardiovascular and autonomic function in Down syndrome - prescribing implications. P.K.Carpenter(C) 118-119

Costs of psychotropic medication. F. Johnstone et al (C) $112-113$

Intramuscular injections in the anticoagulated state. P. Aitken and J. Bolton (C) 269

Lead-in placebo washout period. J. Volavka (C) 694

see also Antidepressants, Antipsychotics, Buspirone, Carbamazepine, Clozapine, Cyproheptadine, Gabapentin, Lithium, Moclobemide, Neuroleptics, Paracetamol, Paroxetine, Risperidone, Sertraline, SSRIsand Valine

\section{DSM-III-R}

Drug trial for panic disorder. Heinz Katschniget al 487-494

Neurasthenia revisited: psychiatric syndromes in chronic fatigue patients. Anne Farmer et al 503-506

Seasonal affective disorder. Christopher Thompson et al 380-384

DSM-IV. Depression in nonagenarians. Y. Forsellet al 61-64

Dysmorphophobia. Does rational role-play enhance the outcome of exposure therapy? Paul Cromarty and Isaac Marks 399402

Dysphoria. Antipsychotic drug-induced. D. J. Kinget al 480 482

Dystonia

Laryngeal. V. Murray (C) 698-699

Neuroleptic medication. R. Thorburn(C) 114

\section{Eating disorders}

Obstacles to innovation in a peripheral hospital. Michael Launer (Editorial) 431-433
Sexual abuse in patients and controls. Christine $M$. Vize and Peter J. Cooper 80-85

see also Anorexia nervosa and Bulimia nervosa

Economicssee Costs

Edinburgh Primary Care Depression Study. Personality disorder and outcome. Douglas A. Patience et al 324-330 Elderty

Age-associated memory impairment. Andrew Barker et al $642-648$

Alleged increase of insanity. Henry Rollin (A hundred years ago) 826

Depression in later life. Comparison of symptoms and risk factors in early and late onset cases. R. C. Baldwin and Barbara Tomenson 649-652

Excess mortality among psychiatric in-patients with organic mental disorder. W. Rössler et al 527-532

Incidence of clinically diagnosed subtypes of dementia in a population. C. Brayne et al 255-262

Late-life depressive disorder. M. Lester and M. Blanchard (C) 822. R. L. van Ojen and W. van Tilburg (Authors'reply) (C) $822-823$

Long-term effects of cognitive-behavioural therapy and lithium therapy on depression. K. C. M. Wilsonet al653658

Prevalence and correlates of depression in nonagenarians. Y. Forsellet al 61-64

Psychiatric symptoms associated with dementia in people with learning disability. Steve Moss and Pradip Patel 663667

Screening test for Alzheimer's disease. Samuel Law and Christina Wolfson 541-544

Electroconvulsive therapy

Seizure threshold. A. I. F. Scott (C) 117

Seizure threshold in bilateral and unilateral ECT. S. Curran and D. Wallace (C)821-822. A. I. F. Scott (Author's reply) (C) 822

Emergent materialism. Biological psychiatry and reductionism.

Hasse Karlsson and Matti Kamppinen (Editorial) 434-438

Emotional salience. Effect on thought disorder in schizophrenia. Gillian Haddocket al 618-620

Epilepsy. Hypomania induced by gabapentin. A. Hauck and S. Bhaumik(C) 549

Episodes of care. First-ever psychiatric patients. Michele Tansella et al 220-227

Ethnic minorities

Anorexia nervosa in 'non-white' populations. G. M. Soomro et al 385-389

Child and adolescent psychiatric presentations of secondgeneration Afro-Caribbeans in Britain. Robert Goodman and Hilary Richards 362-369

Immigrant families coping with schizophrenia. Cynthia Telles et al 473-479

Pathways to care for patients with a first episode of psychosis. Eleanor Coleet al 770-776

Eugenics. Population policy. China. Veronica Pearson (Editorial) 1-4. L. Uzych (C) 697-698

Evolutionary theory. Darwinian approach to the origins of psychosis. T. J. Crow (Review Article) 12-25

Eraminations

Mini-Mental State Examination 541-544, 659-662,(C) 822, (Authors'reply)(C) 822-823 
Present State Examination 193-196,621-628

\section{Exposuretherapy}

Does imagined exposure to the consequences of not ritualising enhance live exposure for $\mathrm{OCD}$ ?

I. Main outcome L. A. de Araujo et al 65-70

II. Effect on behavioural $\mathbf{v}$. subjective concordance of improvement. L. M. Ito et al 71-75

Does rational role-play enhance the outcome in dysmorphophobia? Paul Cromarty and Isaac Marks 399-402

Exposure control of chronic auditory hallucinations in schizophrenia. Rajendra Persaud and Isaac Marks 45-50

Treatment of OCD. I. Marks (C) 411-412

Expressed emotion. Course of schizophrenia in Japan. Shuich Tanaka et al 794-798

Extrapyramidal symptoms. Neuroleptic associated. I. Maurer et al (C) 551-552

Fakirs. Simulation of death. Henry Rollin (A hundred years ago) 119

False memory syndrome. Multiple personality disorder. C. A Ross(C)263-264. K. A. Nakdimen(C)264.C. Haley(C) 264. H. Merskey (Author's reply) (C) 265-266

Families

Functioning in adolescent anorexia nervosa. Clive Northet al 673-678

Immigrant families coping with schizophrenia. Cynthia Telles et al 473-479

Family Assessment Device. Family functioning in adolescent anorexia nervosa. Clive North et al 673-678

Free radicals. Lipid peroxide and vitamin $\mathrm{E}$ in tardive dyskinesia. Robin G. McCreadieet al 610-617

Gabapentin. Induced hypomania. A. Hauck and S. Bhaumik (C) 549

Gender

Differences in parental psychological distress following infant death. John C. Vance et al 806-811

Gender-specific changes since 1900 in the season-of-birth effect in schizophrenia. John M. Eagles et al 469-472

Mortality at the Leros PIKPA Asylum. A. Perakis et al (suppl. 28) 70-77

Schizophrenia. Kenneth S. Kendler and Dermot Walsh 184 192

Genetics

Apolipoprotein E genotype and Alzheimer's disease. Jennie Norrmanet al 533-536

Darwinian approach to the origins of psychosis. T. J. Crow (Review Article) 12-25

Investigation by linkage analysis of the $\mathrm{XY}$ pseudoautosomal region in schizophrenia. Gursharan Kalsiet al 390-393

Gilles de la Tourette's syndrome

Brain perfusion abnormalities. John Moriarty et al 249-254

Visual fields. L. Whitefieldet al (C) 825-826

Greece see Leros PIKPA Asylum

Growth hormone response to apomorphine. Psychotic and depressive symptoms in Parkinson's disease. John D. C. Mellerset al 522-526
Hallucinations

Charles Bonnet syndrome. D. K. Arya (C) 114-115. A. Fernandez and G. Lichtshein (C) 115

Cultural context. F. Klemperer(C) 115-116

Exposure control of chronic auditory hallucinations in schizophrenia. Rajendra Persaud and Isaac Marks 45-50

Hedonic tone. Scale for assessment. Snaith-Hamilton Pleasure Scale. R. P. Snaithet al 99-103. G. Loas and P. Boyer(C) 551

\section{HIVinfection}

Psychiatric patients: a new population at risk? Martin D. Stefan and José Catalán (Review Article) 721-727

Psychological interventions in infection with the virus. Jose Catalan (Clinical Topics in Psychotherapy) 104-111

Home-based care. Statistical design, analysis and further correspondence. I. Marks (C) 270

Homicidal behaviour. Mental disorders. J. Tiihonen et al (C) 821

Hormone replacement therapy. Effects. Psychological and sexual symptoms associated with the menopause. Jane Pearce et al (Review Article) 163-173

Hospitals

Clozapine, eating disorders and substance abuse. Obstacles to innovation in a peripheral hospital. Michael Launer (Editorial) 431-433

Crisis in admission beds. Robin B. Powell et al 765-769

Effectiveness of clozapine in hospitalised people with chronic neuroleptic-resistant schizophrenia. Moshe Avnon and Jonathan Rabinowitz 760-764

Excess mortality among elderly psychiatric in-patients with organic mental disorder. W. Rössler et al 527-532

see also Admission rates and Asylums

5-Hydroxytryptamine see Serotonin

Hypersalivation. Clozapine-induced. Alpha, adrenoceptor. F. M. Corrigan et al (C) 412

Hyperthyroidism. Severe apathetic hyperthyroidism with normal thyroid hormone levels. M. J. Eales and P. van der Merwe(C) 823-824

Hypomania. Induced by gabapentin. A. Hauck and S. Bhaumik (C) 549

ICD-9. Social deprivation and admission rates among different diagnostic groups. Judy Harrison et al 456-462

ICD-10

Depression in nonagenarians. Y. Forsell et al 61-64

Neurasthenia revisited: psychiatric syndromes in chronic fatigue patients. Anne Farmer et al 503-506

Periodic psychosis of puberty revisited. Kazuhiko Abe and MikioOhta 507-513

Immigrants. Families coping with schizophrenia. Cynthia Telles et al 473-479

Infant death. Gender differences in parental psychological distress following perinatal death or Sudden Infant Death Syndrome. John C. Vance et al 806-811

Informant Questionnaire on Cognitive Decline in the Elderly (IQCODE). Screening test for Alzheimer's disease. Samuel Law and Christina Wolfson 541-544

Innovations. Clozapine, eating disorders and substance abuse. Obstacles to innovation in a peripheral hospital. Michael Launer (Editorial) 431-433 
Insight. Psychotic illness. Anthony David et al 621-628 Interviews

Camberwell Family Interview 794-798

McMaster Structured Interview of Family Functioning 673678

Structured Clinical Interview for DSM-III-R 380-384

Intramuscularinjections. In the anticoagulated state. P. Aitken and J. Bolton (C) 269

Jamaica. Incidence of first contact schizophrenia. Frederick W. Hickling and Pamela Rogers-Johnson 193-196

Japan. Expressed emotion and the course of schizophrenia. Shuichi Tanaka et al 794-798

Jealousy. Morbid jealousy in alcoholism. Albert Michaelet al 668-672

Kegworth air disaster. Psychological consequences. W. Gregg et al 812-817

Kraepelin, Emil. Two faces. Michael Shepherd 174-183

Laryngeal dystonia. Neuroleptic medication. $R$. Thorburn (C) 114. V. Murray (C) 698-699

Learning disabilities

Behaviour symptoms among severely and profoundly mentally retarded patients. Andrew $\mathrm{H}$. Reid and Brian R. Ballinger 452-455

Hypomania induced by gabapentin. A. Hauck and S. Bhaumik (C) 549

Psychiatric symptoms associated with dementia in older people. Steve Moss and Pradip Patel 663-667

see also Leros PIKPA Asylum

Lecture. Russian literature and psychiatry. M. Kachaeva 403 406

Leros PIKPA Asylum

Children in institutions. I. Kolvin (Editorial) 8-11

The children of Leros PIKPA. J. Tsiantis (ed.)(suppl. 28) 1-

79

Change in care staff's attitudes towards people with learning disabilities following intervention. $P$. Kordoutis et al 56-69

Conclusions. John Tsiantis 78-79

Deinstitutionalisation and rehabilitation project. $\mathrm{J}$. Tsiantis et al $10-45$

Foreword. John H. Henderson 5-6

Introduction. John Tsiantis 7-9

Mortality among institutionalised people with learning disabilities in Greece. A. Perakis et al 70-77

Psychosocial dynamics of change. J. Tsiantis et al 4655

Lewy body dementia. Diagnosis and treatment. Ian G. McKeith et al (Editorial) 709-717

Life events

Dementia. M. Mobayed and D. Baynes (C) 407-408

Miscarriage. Tom O'Hare and Francis Creed 799-805

Life Events and Difficulties Schedule. Life events and miscarriage. Tom O'Hare and Francis Creed 799-805

Linkage analysis. Investigation of the $\mathrm{XY}$ pseudoautosomal region in schizophrenia. Gursharan Kalsi et al 390-393
Lipid peroxide. Vitamin $\mathrm{E}$ in tardive dyskinesia. Robin G. McCreadie et al 610-617

Lithium

Cognitive-behavioural therapy. Long-term effects on depression in the elderly. K. C. M. Wilson et al 653-658

Revisited. Re-examination of prophylaxis in manicdepressive disorder. J. Moncrieff (Editorial) 569-573. Reply. Guy M. Goodwin (Commentary) 573-574

Liver transplant. Psychosocial outcome. L. M. Howard and T. Fahy (C) 267-268

London. Crisis in admission beds in Greater London. Robin B. Powellet al 765-769

McMaster Structured Interview of Family Functioning. Adolescent anorexia nervosa. Clive North et al 673-678

Magnetic resonance imaging

Cognitive functioning and chronic fatigue. Helen Copeet al 86-94

Functional. Cerebral changes in schizophrenia. J. Schröder et al 197-201

Tardive dyskinesia in schizophrenia. Relationship to minor physical anomalies, frontal lobe dysfunction and cerebral structure. John L. Waddington et al 41-44

Treatment response in schizophrenia. Stephen M. Lawrie et al 202-210

Magnetic resonance spectroscopy. In vivo. Applications in psychiatry. Michael Maier (Review Article) 299-306

Maine and Vermont three-decade studies of serious mental illness. Michael J. DeSisto et al

I. Matched comparison of cross-sectional outcome 331-338

II. Longitudinal course comparisons 338-342

Malingering. Miracles. Henry Rollin (A hundred years ago) 700

Mania

First admission incidence study 1975 to 1981 . Ian Dalyet al 463-468

Precipitated by carbamazepine withdrawal. D. A. Scull and M.R.Trimble(C) 698

Rhabdomyolysis. S. M. Manchip and S. J. Hurel (C) 118

Manic-depression

Lithium revisited. Re-examination of prophylaxis. J. Moncrieff (Editorial) 569-573. Reply. Guy M. Goodwin (Commentary) 573-574

Neuropsychological function. A. P. McKay et al 51-57. S. Bhandari(C) 824-825

see also Bipolar disorder

Media. Influence on parasuicide. Sue Simkinet al 754-759

Memory

Multiple personality disorder and false memory syndrome. C. A.Ross (C) 263-264. K. A.Nakdimen (C) 264.C. Haley (C) 264. H. Merskey (Author's reply) (C) 265-266

Prevalence study of age-associated impairment. Andrew Barkeret al 642-648

Men. Gender differences in parental psychology following infant death. John C. Vance et al 806-811

Menopause. Associated psychological and sexual symptoms and the effects of hormone replacement therapy. Jane Pearce et al (Review Article) 163-173

Mental health services

Episodes of care for first-ever psychiatric patients. Michele Tansella et al 220-227 
Pathways to care for patients with a first episode of psychosis. Comparison of ethnic groups. Eleanor Cole et al 770-776

see also Community care, Hospitals, Primary care and Residential care

Mental health tribunals. H.Crimlisk and M.Phelan(C)116-117

Mental illness see Psychiatric disorders

Mental retardation see Learning disabilities

Mercury poisoning. Neuropsychiatric sequelae. R. E. O'Carroll et al 95-98

Meta-analyses

Obstetric complications and schizophrenia. John R. Geddes and Stephen M. Lawrie 786-793

Publication bias. S. Gilbody and A. House (C) 266

Mind. See Cognitive neuropsychiatry

Mini-Mental State Examination

Late-life depressive disorder. M. Lester and M. Blanchard (C) 822. R. L. van Ojen and W.van Tilburg (Authors'reply) (C) 822-823

Reading ability and Alzheimer's disease. R. E. O'Carroll et al 659-662

Screening for Alzheimer's disease. Samuel Law and Christina Wolfson 541-544

Miscarriage. Life events. Tom O'Hare and Francis Creed 799805

Mitochondrial function

Aspects of oxidative metabolism in schizophrenia. R. M. Marchbanks et al (Editorial) 293-298

Neuroleptic associated extrapyramidal symptoms. I. Maurer et al (C) 551-552

Moclobemide. Clozapine-induced hypotension treated with moclobemide and Bovril. D. Tayloret al (C) 409-410

Modified Manifest Abnormality Scale of the Clinical Interview Schedule. Behaviour symptoms among mentally retarded patients. Andrew H. Reid and Brian R. Ballinger 452-455

Morbidity

Prevalence of psychiatric morbidity among remand prisoners in Scotland. Mark Davidson et al 545-548

Psychological consequences of the Kegworth air disaster. W. Gregget al 812-817

Termination of pregnancy and psychiatric morbidity. Anne C. Gilchristet al 243-248

Mortality

Excess among elderly psychiatric in-patients with organic mental disorder. W. Rössler et al 527-532

Leros PIKPA Asylum. A. Perakis et al (suppl. 28) 70-77

see also Suicide

Mothers. Lone mothers and their children. Jane Roberts (Editorial) 159-162

Movement planning. Relationship to psychopathology profiles in schizophrenia. Ashok K. Malla et al 211-215

MRI see Magnetic resonance imaging

Multiple personality disorder. False memory syndrome.C.A Ross(C)263-264. K. A. Nakdimen(C)264.C. Haley(C) 264. H. Merskey (Author's reply) (C) 265-266

National Adult Reading Test. Reading ability and Alzheimer's disease. R. E. O'Carroll et al 659-662

Need. Camberwell Assessment of Need. Michael Phelan et al 589-595
Neurasthenia. Revisited: ICD-10 and DSM-III-R psychiatric syndromes in chronic fatigue patients. Anne Farmer et al 503-506

Neuroleptics

Associated extrapyramidal symptoms. I. Maurer et al (C) 551-552

Cyproheptadine treatment of induced akathisia. David Weiss et al 483-486

Dystonia. R. Thorburn (C) 114

Laryngeal dystonia. V. Murray (C) 698-699

Self-measure of side-effects. S. Sikdar(C) 113-114

see also Antipsychotics and individual names

Neuropsychiatry

Sequelae of mercury poisoning. R. E. O'Carrollet al 95-98 see also Cognitive neuropsychiatry

Neuropsychological function

Manic-depressive psychosis. A. P. McKay et al 51-57. S. Bhandari(C) 824-825

Slowness in obsessive-compulsive patients. Silvana Galderisi et al 394-398

Nithsdale schizophrenia surveys. XIV: Plasma lipid peroxide and serum vitamin $E$ levels in patients with and without tardive dyskinesia. Robin G. McCreadie et al 610-617

Northiaden. Dothiepin. Effect of exposure in breast milk on child development. Anne Buist and Helen Janson 370-373

Obsessive-compulsive disorder (OCD)

Does imagined exposure to the consequences of not ritualising enhance live exposure?

I. Main outcome L. A. de Araujo et al 65-70

II. Effect on behavioural $v$. subjective concordance of improvement. L. M. Ito et al 71-75

Neuropsychological slowness in patients. Silvana Galderisi et al 394-398

Psychosurgery. R. P. Snaith et al (C) 411

Regional cerebral blood flow in patients at rest. James V. Lucey et al 629-634

Structured abstracts. D. J. Castle (C) 266-267

Treatment. I. Marks (C) $411-412$

Obstetric complications

Schizophrenia. L. Rifkin and N. Takei (C) 694-695. P. B. Mortensen et al (C) 695-696. D. J. Done and A. Sacker (Authors'reply)(C) 696-697

Schizophrenia: a meta-analysis. John R. Geddes and Stephen M. Lawrie 786-793

Offenders. Young offenders, serious crimes. Susan Bailey (Editorial) 5-7

Organic mental disorders. Excess mortality among elderly psychiatric in-patients. W. Rössler et al 527-532

Oxidative metabolism. Aspects in schizophrenia. R. M. Marchbanks et al (Editorial) 293-298

\section{Panic disorder}

Comorbidity and suicide risk. M.M. Weissman (C) 819-820

Long-term follow-up after a drug trial. Heinz Katschnig et al 487-494

Paroxetine in treatment. S. Oehrberg et al 374-379

Suicide attempt. Christopher D. Hornig and Richard J. McNally 76-79 
With agoraphobia. Cognitive behaviour therapy with buspirone or placebo. Jean Cottraux et al 635-641

Paracetamol. Media influence on parasuicide. Effects of a television drama portrayal of self-poisoning. Sue Simkinet al 754-759

Parasuicide. Media influence. Effects of a television drama portrayal of paracetamol self-poisoning. Sue Simkin et al 754-759

Parents. Gender differences in psychological distress following infant death. John C. Vance et al 806-811

Parkinson's disease. Psychotic and depressive symptoms. Study of the growth hormone response to apomorphine. John D. C. Mellers et al 522-526

Paroxetine. Treatment of panic disorder. S. Oehrberget al 374 379

Patients. Psychiatric patients and HIV infection: a new population at risk? Martin D. Stefan and JoséCatalán (Review Article) 721-727

Personality disorder

Edinburgh Primary Care Depression Study. Personality disorder and outcome. Douglas A. Patienceet al 324-330

Fifteen to twenty year follow-up of adult psychiatric patients. David Quinton et al 315-323

Philosophy

Biological psychiatry and reductionism. Hasse Karlsson and Matti Kamppinen (Editorial) 434-438

Psychiatry. Michael Shepherd (Editorial) 287-288

Post-concussional state. Neurophysiological aspects. M. R. Watson et al 514-521

Post-traumatic stress disorder

Medium-term course of disaster victims. C. Duggan and J. Gunn 228-232

Psychological consequences of Kegworth air disaster. W. Gregget al 812-817

Psychological debriefing techniques within a brief group psychotherapy programme. Walter Busuttilet al 495-502

Psychological reactions of victims of violent crime. Jonathan I. Bisson and Jonathan P. Shepherd (Editorial) 718-720

Pregnancy

Breastfeeding. Antidepressants. D. A. Ratan and T. Friedman (C) 824

Life events and miscarriage. Tom O'Hare and Francis Creed 799-805

Suspected congenital sertraline dependence. L. S. W. Kent and J. D. D. Laidlaw (C) 412-413

Termination and psychiatric morbidity. Anne C. Gilchristet al 243-248

Presenile Alzheimer's disease

Community care. M. Evans (C) 408

Epidemiology in Scotland(1974 to 1988). Lawrence J. Whalley et al

I. Non-random geographical variation 728-731

II. Exposures to possible risk factors 732-738

Present State Examination

First contact schizophrenia in Jamaica. Frederick W. Hickling and Pamela Rogers-Johnson 193-196

Insight and psychotic illness. Anthony Davidet al 621-628

Primary care. Edinburgh Primary Care Depression Study. Personality disorder and outcome. Douglas A. Patienceet al 324-330

Prisoners. Prevalence of psychiatric morbidity among remand prisoners in Scotland. Mark Davidson et al 545-548
Pseudoautosomal region. Investigation by linkage analysis of the XY pseudoautosomal region in schizophrenia. Gursharan Kalsiet al 390-393

Psychiatric Assessment Schedule for Adults with a Developmental Disability (PAS-ADD). Dementia in older people with learning disability. Steve Moss and Pradip Patel 663-667

Psychiatric case registers. Episodes of care for first-ever psychiatric patients. Michele Tansella et al 220-227

Psychiatric disorders

Alleged increase of insanity. Henry Rollin (A hundred years ago) 826

Child and adolescent psychiatric presentations of secondgeneration Afro-Caribbeans in Britain. Robert Goodman and Hilary Richards 362-369

Chinese classification. Sing Lee (C) 117-118

Community-based psychiatric care for people with treated long-term mental illness. Greg Wilkinsonet al 26-37. Ian Pullen and Tony Kendrick (Comment) 38-40

Deprivation and admission rates among different diagnostic groups. Judy Harrison et al 456-462

Fifteen to twenty year follow-up of adult psychiatric patients. David Quinton et al 315-323

Homicidal behaviour and mental disorders. J. Tiihonenet al (C) 821

Maine and Vermont three-decade studies of serious mental illness. Michael J. DeSistoet al 331-338, 338-342

Neurasthenia revisited: ICD-10 and DSM-III-R syndromes in chronic fatigue patients. Anne Farmer et al 503-506

Prevalence of morbidity among remand prisoners in Scotland. Mark Davidson et al 545-548

Psychological consequences of the Kegworth air disaster. W. Gregget al 812-817

Psychological reactions of victims of violent crime. Jonathan I. Bisson and Jonathan P. Shepherd (Editorial) 718-720

Severe. Camberwell Assessment of Need. Michael Phelanet al 589-595

Termination of pregnancy and morbidity. Anne C. Gilchrist et al 243-248

Psychiatry

Philosophy. Michael Shepherd (Editorial) 287-288

Psychiatry in Dissent. Anthony Clare (Louis Appleby) (Books reconsidered) 555-556

Russian literature. M. Kachaeva (Lecture) 403-406

Psychological debriefing

A. B. Gillham (C) 407

Incorporating techniques within a brief group psychotherapy programme for post-traumatic stress disorder. Walter Busuttilet al 495-502

Psychoses

Associations of psychotic symptoms in dementia sufferers. Clive Ballardet al 537-540

Darwinian approach to the origins. T. J. Crow (Review Article) 12-25

Delineation of acute and transient disorders in a developing country setting. Ezra Susser et al 216-219

Hypomania induced by gabapentin. A. Hauck and S. Bhaumik (C) 549

Insight and psychotic illness. Anthony David et al 621-628

Neuropsychological function in manic-depressive psychosis. A. P. McKayet al 51-57. S. Bhandari(C) 824 825 
Pathways to care for patients with a first episode of psychosis. Comparison of ethnic groups. Eleanor Coleet al 770-776

Periodic psychosis of puberty revisited. Kazuhiko Abe and MikioOhta 507-513

Psychotic and depressive symptoms in Parkinson's disease. John D. C. Mellers et al 522-526

Somatic delusions in schizophrenia and the affective psychoses. Iain McGilchrist and John Cutting 350-361

Psychosurgery. Obsessional disorder. R.P. Snaithet al (C) 411

Psychotherapy

Bipolar disorder. Jan Scott (Review Article) 581-588

Psychological debriefing techniques within a brief group programme. Walter Busuttilet al 495-502

Psychological interventions in infection with HIV. Jose Catalan (Clinical Topics in Psychotherapy) 104-111

Psychological treatments for depression. Jan Scott(Editorial) 289-292

Supportive. Search for positive meanings. Jeremy Holmes (Review Article) 439-445. Margaret F. Robertson and Peter Tyrer (Peer Review) 446-447

Treatment of sexual dysfunctions by sex therapy. Keith Hawton (Clinical Topics in Psychotherapy) 307-314

see also Behavioural family management, Cognitive behavioural therapy andExposure therapy

Publication bias. Meta-analysis. S. Gilbody and A. House (C) 266

\section{Rating scales see Scales}

Rational role-play. Does it enhance the outcome of exposure therapy in dysmorphophobia? Paul Cromarty and Isaac Marks 399-402

Reading ability. Further evidence that it is not preserved in Alzheimer's disease. R. E. O'Carrollet al 659-662

Reductionism. Biological psychiatry. Hasse Karlsson and Matti Kamppinen (Editorial) 434-438

Research. Improving the quality of statistics in psychiatric research. David Hand and Pak Sham (Commentary) 689-691

Residential care. Repeat prescription antidepressants. A Farmer(C) 408-409

Rhabdomyolysis. Due to mania. S. M. Manchip and S. J. Hurel (C) 118

Risperidone. Response after no clozapine response. M. Avnon and A. Kunin (C) 699

Russian literature. Psychiatry. M. Kachaeva (Lecture) 403406

Scales

Abnormal Involuntary Movement Scale 41-44, 610-617

BriefPsychiatric Rating Scale 760-764, 794-798

Clinician-Administered PTSD Scale (CAPS) 228-232

Modified Manifest Abnormality Scale of the Clinical Interview Schedule 452-455

Self-measure of neuroleptic side-effects. S. Sikdar(C) 113 114

Snaith-Hamilton Pleasure Scale 99-103,(C) 551

see also Burns' Symptom Checklist, Camberwell Assessment of Need, Examinations, Family Assessment Device, Informant Questionnaire on Cognitive Decline in the Elderly, Interviews, National Adult Reading Test and Schedules
Schedules

Life Events and Difficulties Schedule 799-805

Psychiatric Assessment Schedule for Adults with a Developmental Disability 663-667

Schedule for the Clinical Assessment of Neuropsychiatry 503-506

Schizophrenia

Aetiology

Investigation by linkage analysis of the $\mathrm{XY}$ pseudoautosomal region in the genetic susceptibility. Gursharan Kalsiet al 390-393

Obstetric complications. L. Rifkin and N. Takei(C) 694 695. P. B. Mortensenet al (C) 695-696. D. J. Done and A. Sacker (Authors' reply)(C) 696-697

Obstetric complications: a meta-analysis. John R. Geddes and Stephen M. Lawrie 786-803

Complications

Nithsdale surveys. XIV: Plasma lipid peroxide and serum vitamin $E$ levels in patients with and without tardive dyskinesia. Robin G. McCreadie et al 610-617

Tardive dyskinesia. Relationship to minor physical anomalies, frontal lobe dysfunction and cerebral structure on MRI. John L. Waddington et al 41-44

Epidemiology

Gender. Results of a family study. Kenneth S. Kendler and Dermot Walsh 184-192

Gender-specific changes since 1900 in the season-ofbirth effect. John M. Eagles et al 469-472

Incidence of first-contact schizophrenia in Jamaica. Frederick W. Hickling and Pamela Rogers-Johnson 193-196

Month and hemisphere of birth. John McGrathet al 783785

Time trends in care-based incidence. A. J. Oldehinkel and R. Giel 777-782

Genetics. Investigation by linkage analysis of the $\mathrm{XY}$ pseudoautosomal region. Gursharan Kalsiet al 390-393

Outcome

Characteristics at 13 years. Peter Mason et al 596-603

Determinants of the extremes. E. C. Johnstoneet al 604 609

Physiopathology

Aspects of oxidative metabolism. R. M. Marchbanks et al (Editorial) 293-298

MRI and SPET in treatment-responsive and treatmentresistant patients. Stephen M. Lawrie et al 202-210

Regional brain activity in chronic patients during a verbal fluency task. C. D. Frithet al 343-349

Relationship between movement planning and psychopathology profiles. Ashok K. Malla et al 211215

Sensorimotor cortex and supplementary motor area changes. Study with fMRI. J. Schröder et al 197-201

Somatic delusions. Iain McGilchrist and John Cutting $350-361$

Tardive dyskinesia. Relationship to minor physical anomalies, frontal lobe dysfunction and cerebral structure on MRI. John L. Waddington et al 41-44

Psychology

Effect of emotional salience on thought disorder in patients. Gillian Haddocket al 618-620 
Expressed emotion and course in Japan. Shuichi Tanaka et al 794-798

Therapy

Effectiveness of clozapine in hospitalised people with chronic neuroleptic-resistant schizophrenia. Moshe Avnon and Jonathan Rabinowitz 760-764

Exposure control of chronic auditory hallucinations. Rajendra Persaud and Isaac Marks 45-50

Immigrant families. Behavioural family intervention $v$. case management. Cynthia Telles et al 473-479

Informed consent in chronic schizophrenia? Gareth $\mathrm{H}$ Jones (Editorial) 565-568

Keeping count for the community. M. Blackwell(C) 823

Risperidone response after no clozapine response. $M$.

Scotland Avnon and A. Kunin (C) 699

Epidemiology of presenile Alzheimer's disease (1974 to 1988). Lawrence J. Whalley et al

I. Non-random geographical variation 728-731

II. Exposures to possible risk factors 732-738

Prevalence of psychiatric morbidity among remand prisoners. Mark Davidson et al 545-548

see also Edinburgh Primary Care Depression Study and Nithsdale schizophrenia surveys

Seasonal affective disorder. Follow-up study. Christopher Thompson et al 380-384

Seasonality

Gender-specific changes since 1900 in the season-of-birth effect in schizophrenia. John M. Eagles et al 469-472

Is there a seasonal pattern of relapse in bipolar affective disorder? Trevor Silverstone et al 58-60

Month and hemisphere of birth and schizophrenia. John McGrathet al 783-785

Selective serotonin reuptake inhibitors

Five group comparisons of treatments for anxiety disorders. D. M. Sharpet al (C) 820-821

Tricyclic antidepressants in combination. David Taylor (Review Article) 575-580

see also Paroxetine and Sertraline

Serotonin. Effect of valine on 5-HT-mediated prolactin release in healthy volunteers, and on mood in remitted depressed patients. D. J. Williamson et al 238-242

Serotonin syndrome. Extreme suicidality following. M. A. Serfaty et al (C) 410

Sertraline

Antidepressants in pregnancy and breastfeeding. D. A. Ratan and T. Friedman (C) 824

Suspected congenital dependence. L. S. W. Kent and J. D. D. Laidlaw(C) $412-413$

Sex therapy. Treatment of sexual dysfunctions. Keith Hawton (Clinical Topics in Psychotherapy) 307-314

Sexual abuse

Patients with eating disorder, patients with depression, and controls. Christine M. Vize and Peter J. Cooper 80-85

Significance of a history of childhood sexual abuse in bulimia nervosa. Patrick F. Sullivanet al 679-682

Sexual dysfunctions. Treatment by sex therapy and other approaches. Keith Hawton (Clinical Topics in Psychotherapy) 307-314

Single photon emission tomography

Brain perfusion abnormalities in Tourette's syndrome. John Moriarty et al 249-254
Regional cerebral blood flow in OCD patients at rest. James V. Luceyet al 629-634

Structured abstracts. D. J. Castle (C) 266-267

Treatment response in schizophrenia. Stephen M. Lawrie et al 202-210

Snaith-Hamilton Pleasure Scale. Assessment of hedonic tone. R. P. Snaithet al 99-103. G. Loas and P. Boyer (C) 551

Social factors

Deprivation and psychiatric admission rates among different diagnostic groups. Judy Harrison et al 456-462

Fifteen to twenty year follow-up of adult psychiatric patients. Psychiatric disorder and social functioning. David Quinton et al 315-323

Suicide. Martti E. Heikkinenet al 747-753

Somatic delusions. Schizophrenia and the affective psychoses. Iain McGilchrist and John Cutting 350-361

SPET see Single photon emission tomography

SSRIs see Selective serotonin reuptake inhibitors

Statistics

Design, analysis and further correspondence. I. Marks (C) 270

Obstetric complications and schizophrenia: a meta-analysis. John R. Geddes and Stephen M. Lawrie 786-793

Publication bias and meta-analysis. S. Gilbody and A. House (C) 266

Use in the British Journal of Psychiatry. S. M. McGuigan 683-688. Improving their quality in psychiatric research. David Hand and Pak Sham (Commentary) 689-691

Structured abstracts. D. J. Castle (C) 266-267

Structured Clinical Interview for DSM-III-R. Seasonal affective disorder. Christopher Thompson et al 380-384

Substance misuse

Blu-Tack-a novel substance of abuse. M. Walker-Kinnear and T. Jones (C) 550-551

Obstacles to innovation in a peripheral hospital. Michael Launer (Editorial) 431-433

Prevalence of psychiatric morbidity among remand prisoners in Scotland. Mark Davidson et al 545-548

see also Alcohol misuse

Suicide

Comorbidity and risk. M. M. Weissman (C) 819-820

Extreme suicidality following serotonin syndrome. M. A Serfaty et al (C) 410

Media influence on parasuicide. Sue Simkin et al 754-759

Nine pacts. Martin Brownet al 448-451

Panic disorder and attempt. Christopher D. Hornig and Richard J. McNally 76-79

Social factors. Martti E. Heikkinen et al 747-753

Supportive psychotherapy. Search for positivemeanings. Jeremy Holmes (Review Article) 439-445. Margaret F. Robertson and Peter Tyrer (Peer Review) 446-447

Symptoms

Associations of psychotic symptoms in dementia sufferers. Clive Ballardet al 537-540

Behaviour symptoms among severely and profoundly mentally retarded patients. Andrew H. Reid and Brian R. Ballinger 452-455

Neuroleptic associated extrapyramidal symptoms. I. Maurer et al (C) 551-552

Psychiatric symptoms associated with dementia in older people with learning disability. Steve Moss and Pradip Patel 663-667 
Psychological and sexual symptoms associated with the menopause and the effects of hormone replacement therapy. Jane Pearce et al (Review Article) 163-173

Psychological effects of disaster at sea. E. Dooley and J. Gunn 233-237

Psychotic and depressive symptoms in Parkinson's disease. John D. C. Mellerset al 522-526

\section{Tardive dyskinesia}

Brain damage. A.Al-Adwani (C) 410-411

Nithsdale schizophrenia surveys. XIV: Plasma lipid peroxide and serum vitamin $E$ levels in patients with and without tardive dyskinesia. Robin G. McCreadie et al 610-617

Schizophrenia. Relationship to minor physical anomalies, frontal lobe dysfunction and cerebral structure on MRI. John L. Waddington et al 41-44

Thought disorder. Effect of emotional salience. Patients with schizophrenia. Gillian Haddocket al 618-620

Thyroid hormones. Severe apathetic hyperthyroidism with normal levels. M. J. Eales and P. van der Merwe (C) 824

Tourette's syndrome see Gilles de la Tourette syndrome

Tricyclics. SSRIs in combination. David Taylor (Review Article) 575-580

Valine. Effect on 5-HT-mediated prolactin release in healthy volunteers, and on mood in remitted depressed patients. D. J. Williamsonet al 238-242

Vascular disease. Depression in later life. R. C. Baldwin and Barbara Tomenson 649-652

Violence

Homicidal behaviour and mental disorders. J. Tiihonenet al (C) 821

Psychological reactions of victims of violent crime. Jonathan

I. Bisson and Jonathan P. Shepherd (Editorial) 718-720

Visual fields. Gilles de la Tourette syndrome. L. Whitefield et al (C) 825-826

Vitamin E. Lipid peroxide and serum levels in patients with and without tardive dyskinesia. Robin G. McCreadie et al 610 617

Washout period. Lead-in placebo washout period. J. Volavka (C) 694

Withdrawal syndromes. Suspected congenital sertraline dependence. L. S. W. Kent and J.D. D. Laidlaw (C) 412-413

Women

Response to adversity. G. C. Mezey (C) 266

Significance of a history of childhood sexual abuse in bulimia nervosa. Patrick F. Sullivanet al 679-682 see also Gender, Menopause, Mothers andPregnancy

\section{PARTII. CONTRIBUTORS}

Abe, Kazuhiko andOhta, Mikio. Recurrent brief episodes with psychotic features in adolescence: periodic psychosis of puberty revisited 507-513
Abou-Saleh, M. see Wilson, K.C.M. et al 653-658

Aguilar, Omar see Malla, Ashok K. et al 211-215

Aitken, P. and Bolton, J. Intramuscular injections in the anticoagulated state (C) 269

Aizenberg, Dov see Weiss, David et al 483-486

Al-Adwani, A. Brain damage and tardive dyskinesia (C) 410411

Amador, Xavier F. see Susser, Ezraet al 216-219

Amering, Michaela see Katschnig, Heinz et al 487-494

Appleby, Louis. Psychiatry in Dissent. Anthony Clare (Books reconsidered) 555-556

Arias, Miguel see Telles, Cynthia et al 473-479

Aro, Hillevi M. see Heikkinen, Martti E. et al 747-753

Arya, D. K. Charles Bonnet syndrome (C) 114-115

Ashikaga, Takamaru see DeSisto, Michael J. et al 331-338, 338-342

Assimopoulos, H. see Tsiantis, J. et al (suppl. 28) 46-55

Avnon, M. andKunin, A. Risperidone response afterno clozapine response (C) 699

Avnon, Moshe and Rabinowitz, Jonathan. Effectiveness of clozapine in hospitalised people with chronic neurolepticresistant schizophrenia 760-764

Babu, V.S. see Michael, Albert et al 668-672

Bailey, Susan. Young offenders, serious crimes (Editorial) 5 7

Baldwin, R.C. andTomenson, Barbara. Depression in later life. A comparison of symptoms and risk factors in early and late onset cases 649-652

Balestrieri, Matteo see Tansella, Michele et al 220-227

Ballard, Clive et al. Associations of psychotic symptoms in dementia sufferers $537-540$

Ballenger, James C. see Katschnig, Heinz et al 487-494

Ballinger, Brian R. see Reid, Andrew H.452-455

Bannister, Carol see Ballard, Clive et al 537-540

Barker, Andrew et al. A prevalence study of age-associated memory impairment 642-648

Barkley, C. see Brayne, C. et al 255-262

Barraclough, Brian see Brown, Martin et al 448-451

Barrow, Steve see Harrison, Judy et al 456-462

Baudendistel, K.see Schröder, J. et al 197-201

Baynes, D. see Mobayed, M.(C) 407-408

Bebbington, P. E. seeJönsson, B. (Authors'reply)(C) 112

Beecham, J.see McCrone, P.et al (Authors'reply) (C) 268-269

Behnke, K. see Oehrberg, S. et al 374-379

Bell, P. see Gregg, W. et al 812-817

Bennedsen, B. see Mortensen, P. B. et al (C) 695-696

Bentall, Richard P. see Haddock, Gillianet al 618-620

Bentall, Richard P. Brains, biases, deficits and disorders (Commentary) 153-155

Bernard, Geneviève see Cottraux, Jean et al 635-641

Best, Jonathan J. K.see Lawrie, Stephen M. et al 202-210

Besthorn, Christoph see Förstl, Hanset al 739-746

Bhandari, S. Neuropsychological function in manic-depressive psychosis (C) 824-825

Bhaumik, S. see Hauck, A. (C) 549

Biggeri, Annibalesee Tansella, Michele et al 220-227

Bisoffi, Giuliasee Tansella, Michele et al 220-227

Bisson, Jonathan I. andShepherd, Jonathan P. Psychological reactions of victims of violent crime (Editorial) 718-720

Black, Roger see Whalley, Lawrence J. et al 728-731 
Blackwell, M. Keeping count for the community (C) 823 Blake, Flona see Pearce, Jane et al (Review Article) 163-173 Blanch, Nick see Busuttil, Walter et al 495-502

Blanchard, M. see Lester, M. (C) 822

Blanes, Tomas see Lucey, James V. et al 629-634

Bolton, J.see Aitken, P. (C) 269

Borup, A. L. see Oehrberg, S. et al 374-379

Borysiewicz, Leszek see Farmer, Anne et al 503-506

Bouvard, Martinesee Cottraux, Jean et al 635-641

Boyer, P. see Loas, G. (C) 551

Boyle, Frances M. see Vance, John C. et al 806-811

Brayne, C.et al. Incidence of clinically diagnosed subtypes of dementia in an elderly population. Cambridge project for later life 255-262

Brazier, D. J. see Whitefield, L. et al (C) 825-826

Briggs, Andrew see Katschnig, Heinz et al 487-494

Bronks, I. G. Case reports and confidentiality (C) 552-553

Brookes, Anthony J. see Norrman, Jennie et al 533-536

Brooks, George W. see DeSisto, Michael J. et al 331-338, 338-342

Brown, Martin et al. Nine suicide pacts. A clinical study of a consecutive series 1974 to $1993.448-451$

Brynjolfsson, Jon see Kalsi, Gursharan et al 390-393

Buckley, Peter see Waddington, John L. et al 41-44

Buist, Anne andJanson, Helen. Effect of exposure to dothiepin and northiaden in breast milk on child development 370-373

Bulik, Cynthia M. see Sullivan, Patrick F. et al 679-682

Buller, Raimund see Katschnig, Heinz et al 487-494

Burke, M. see King, D. J. et al $480-482$

Burns, R.see Wilson, K. C. M. et al 653-658

Burns, T. Costs of community psychiatric nurse teams (C) 268

Busatto, Geraldo F.see Lucey, James V. et al 629-634

Busuttil, Walteret al. Incorporating psychological debriefing techniques within a brief group psychotherapy programme for post-traumatic stress disorder 495-502

Butler, Robertsee Kalsi, Gursharan et al 390-393

Byram, Victoriasee North, Clive et al 673-678

Byrne, E. Jane see McKeith, Ian G. et al (Editorial) 709-717

Cahill, C. see Frith, C. D. et al 343-349

Calberg, H. see Oehrberg, S. et al 374-379

Campbell, Graham see McCreadie, Robin G. et al 610-617

Carnahan, Heather see Malla, Ashok K. et al 211-215

Carpenter, P. K. Cardiovascular and autonomic function in Down syndrome - prescribing implications (C) 118-119

Carter, Frances A.see Sullivan, Patrick F. et al 679-682

Cassano, Giovanni see Katschnig, Heinz et al 487-494

Castle, D. J. Structured abstracts (C) 266-267

Catald́n, Josésee Stefan, Martin D. (Review Article) 721-727

Catalán, José. Psychological interventions in infection with the human immunodeficiency virus (Clinical Topics in Psychotherapy) 104-111

Catapano, Francesco see Galderisi, Silvana et al 394-398

Chalder, T. Chronic fatigue syndrome (C) 549-550

Chariton, Bruce G. Cognitive neuropsychiatry and the future of diagnosis: a 'PC' model of the mind (Editorial) 149-153

Chneiweiss, Laurent see Cottraux, Jean et al 635-641

Christiansen, P. E. see Oehrberg, S. et al 374-379

Cole, Eleanor et al. Pathways to care for patients with a first episode of psychosis. A comparison of ethnic groups 770 776
Conover, Sarahsee Susser, Ezraet al 216-219

Cooper, Peter J. see Vize, Christine M. 80-85

Cope, H. and David, A. Cognitive functioning with chronic fatigue (Authors' reply)(C) 818-819

Cope, Helen et al. Cognitive functioning and magnetic resonance imaging in chronic fatigue 86-94

Copeland, J.R. M.see Wilson, K. C. M. et al 653-658

Corrigan, F. M.et al. Clozapine-induced hypersalivation and the alpha 2 adrenoceptor (C) 412

Cortese, Leonard see Malla, Ashok K. et al 211-215

Costa, Durval C. see Lucey, James V. et al 629-634

Costa, Durval Campossee Moriarty, John et al 249-254

Cottranx, Jean et al. A controlled study of cognitive behaviour therapy with buspirone or placebo in panic disorder with agoraphobia 635-641

Cowen, P. J. see Williamson, D. J. et al 238-242

Creed, Francis see Harrison, Judy et al 456-462

Creed, Francissee O'Hare, Tom799-805

Crimlisk, H. and Phelan, M. Mental health tribunals (C) 116117

Crisp, A. H. see Soomro, G. M. et al 385-389

Cromarty, Paul and Marks, Isaac. Does rational role-play enhance the outcome of exposure therapy in dysmorphophobia? A case study 399-402

Croudace, Tim see Mason, Peter et al 596-603

Crow, T.J. A Darwinian approach to the origins of psychosis (Review Article) 12-25

Cungi, Charlysee Cottraux, Jean et al 635-641

Cunningham Owens, David G. see Davidson, Mark et al 545548

Curran, P. see Gregg, W.et al 812-817

Curran, S. and Wallace, D. Seizure threshold in bilateral and unilateral ECT(C) $821-822$

Curtis, Davidsee Kalsi, Gursharan et al 390-393

Cutting, John see McGilchrist, Iain 350-361

Dalkin, Tim see Mason, Peter et al 596-603

Daly, Ian et al. First admission incidence study of mania, 1975 to $1981.463-468$

D'Amato, Alessandro Coluccisee Galderisi, Silvana et al 394-398

David, A.see Cope, H. (Authors' reply)(C) 818-819

David, Anthony see Cope, Helenet al $86-94$

David, Anthony. The future of diagnosis (Commentary) 155157

David, Anthony et al. Insight and psychotic illness. Crosssectional and longitudinal associations $621-628$

Davidson, Mark et al. Prevalence of psychiatric morbidity among remand prisoners in Scotland 545-548

Deale, A. see de Aranjo, L. A. et al 65-70

de Araujo, L. A.see Ito, L. M. et al 71-75

de Araujo, L. A. et al. Does imagined exposure to the consequences of not ritualising enhance live exposure for OCD? A controlled study. I. Main outcome 65-70

deSisto, Michael J. et al. The Maine and Vermont three-decade studies of serious mental illness

I. Matched comparison of cross-sectional outcome 331-338

II. Longitudinal course comparisons 338-342

Dimond, B. Case reports and confidentiality (Author's reply) (C) $553-554$

Dolan, R. J.see Frith, C. D. et al 343-349 
Done, D. J. and Sacker, A. Obstetric complications in schizophrenia (Authors' reply)(C) 696-697

Dooley, E. and Gunn, J. The psychological effects of disaster at sea 233-237

Dougall, N. see O'Carroll, R. E. et al 95-98

Duggan, C. and Gunn, J. Medium-term course of disaster victims. A naturalistic follow-up 228-232

Dunn, Graham see Phelan, Michael et al 589-595

Eagle, Matthew see Simkin, Sue et al 754-759

Eagles, John M. et al. Gender-specific changes since 1900 in the season-of-birth effect in schizophrenia 469-472

Eales, M. J. and Merwe, P. van der. Severe apathetic hyperthyroidism with normal thyroid hormone levels (C) 823-824

Eaton, W. W. see Mortensen, P. B. et al (C) 695-696

Ebmeier, K. P.see O'Carroll, R. E. et al 95-98, 659-662

Ebmeier, Klaus P.see Lawrie, Stephen M. et al 202-210

Eccleston, D. see Serfaty, M. A. et al (C) 410

Ell, Peter J.see Lucey, James V. et al 629-634

EIl, Peter J.see Moriarty, John et al 249-254

Ennis, Joseph T.see Waddington, John L. et al 41-44

Eronen, M. see Tiihonen, J. et al (C) 821

Evans, M. Community care in presenile Alzheimer's disease (C) 408

Fagg, Joan see Simkin, Sue et al 754-759

Fahy, T.see Howard, L.M.(C) 267-268

Fahy, Thomassee David, Anthony et al 621-628

Fairweather, D. B. see Kerr, J. S. et al (C) 413

Faivre, F. see Taylor, D.et al (C) 409-410

Falloon, Ian see Wilkinson, Greg et al 26-37

Farmer, A. Repeat prescription antidepressants and residential care(C) 408-409

Farmer, Anne et al. Neurasthenia revisited: ICD-10 and DSMIII-R psychiatric syndromes in chronic fatigue patients and comparison subjects 503-506

Fätkenheuer, B. see Rössler, W. et al 527-532

Fenton, G. W.see Watson, M. R.et al 514-521

Fernandez, A. and Lichtshein, G. Charles Bonnet syndrome (C) 115

Fletcher, P. see Frith, C. D. et al 343-349

Foerster, Alicesee David, Anthony et al 621-628

Forsell, Y. et al. Prevalence and correlates of depression in a population of nonagenarians 61-64

Förstl, Hans et al. Brain atrophy in normal ageing and Alzheimer's disease. Volumetric discrimination and clinical correlations 739-746

Fowler-Dixon, R. see Gregg, W. et al 812-817

Frackowiak, R. S. J.see Frith, C. D. et al 343-349

Frank, Peter see Gilchrist, Anne C. et al 243-248

Freeman, Christopher P. L. see Patience, Douglas A. et al 324-330

Freeman, H. see O'Hanlon, J. F. (Authors'reply)(C)413-414

Friedman, T. see Ratan, D.A.(C) 824

Friston, K. J.see Frith, C. D. et al 343-349

Frith, C. D. see Johnstone, E. C. et al 604-609

Frith,C.D.et al. Regional brain activity in chronic schizophrenic patients during the performance of a verbal fluency task 343-349
Galasko, Douglas see McKeith, Ian G.et al (Editorial) 709-717

Galderisi, Silvana et al. Neuropsychological slowness in obsessive-compulsive patients. Is it confined to tests involving the fronto-subcortical systems? 394-398

Garvey, Michaelsee Katschnig, Heinz et al 487-494

Geddes, J. see Harrison, P. J. (C) 692

Geddes, John R. see Eagles, John M. et al469-472

Geddes, John R. and Lawrie, Stephen M. Obstetric complications and schizophrenia: a meta-analysis 786793

Gehlhaar, E.see Brayne, C. et al 255-262

Geiger-Kabisch, Claudiasee Förstl, Hanset al 739-746

Giel, R.see Oldehinkel, A.J. 777-782

Gilbody, S. and House, A. Publication bias and meta-analysis (C) 266

Gilchrist, Anne C. et al. Termination of pregnancy and psychiatric morbidity 243-248

Gill, C.see Brayne, C. et al 255-262

Gillham, A. B. Psychological debriefing (C) 407

Girling, D. M.see Brayne, C. et al 255-262

Glazebrook, Cristinesee Mason, Peter et al 596-603

Goodman, Robert andRichards, Hilary. Child and adolescent psychiatric presentations of second-generation AfroCaribbeans in Britain 362-369

Goodwin, G. M.see O'Carroll, R. E. et al 95-98, 659-662

Goodwin, Guy M.see Lawrie, Stephen M. et al 202-210

Goodwin, Guy M. Lithium revisited. A reply (Commentary) 573574

Goudsmit, E. M. and Howes, S. Cognitive functioning with chronic fatigue (C) 818

Gowers, Simonsee North, Clive et al 673-678

Graham, Candida see Ballard, Clive et al 537-540

Gregg, W. et al. Psychological consequences of the Kegworth airdisaster 812-817

Gulliver, Lesley see Quinton, David et al 315-323

Gunn, J.see Dooley, E. 233-237

Gunn, J.see Duggan, C.228-232

Gurling, Hugh M. D. see Kalsi, Gursharan et al 390-393

Haddock, Gillian et al. Effect of emotional salience on thought disorder in patients with schizophrenia 618-620

Hakola, P. see Tilhonen, J. et al (C) 821

Haley, C. Multiple personality disorder and false memory syndrome (C) 264

Halligan, Peter W.see Marshall, John C. (Commentary) 157158

Hamilton, M. see Snaith, R.P.et al 99-103

Hand, David and Sham, Pak. Improving the quality of statistics in psychiatric research (Commentary) 689-691

Hannaford, Philip C. see Gilchrist, Anne C. et al 243-248

Harding, Courtenay M.see DeSisto, Michael J. et al 331338, 338-342

Hargreaves, D. see Snaith, R. P. et al 99-103

Harrison, G.see Gregg, W. et al 812-817

Harrison, Glynnsee Mason, Peter et al 596-603

Harrison, Judy et al. Social deprivation and admission rates among different diagnostic groups $456-462$

Harrison, P.J. andGeddes, J. A 'PC' model of the mind(C) 692

Hartman, D.A 'PC' model of the mind(C) 693

Harvey, Iansee David, Anthony et al 621-628 
Hauck, A. andBhaumik, S. Hypomania induced by gabapentin (C) 549

Hawton, Keithsee Pearce, Jane et al (Review Article) 163-173

Hawton, Keithsee Simkin, Sue et al 754-759

Hawton, Keith. Treatment of sexual dysfunctions by sex therapy and other approaches (Clinical Topics in Psychotherapy) 307-314

Hayward, Petersee Phelan, Michael et al 589-595

Headley, M. see Watson, M. R.et al 514-521

Healy, D. see Johnstone, F. et al (C) 112-113

Heikkinen, Martti E. et al. Social factors in suicide 747-753

Heim, Françoissee Cottraux, Jean et al 635-641

Hemsley, D. see Ito, L. M. et al 71-75

Henderson, John H. Foreword (suppl. 28) 5-6

Hentschel, Frank see Förstl, Hanset al 739-746

Herepath, Ronaldsee Busuttil, Walteret al 495-502

Hermesh, Haggaisee Weiss, David et al 483-486

Herold, S.see Frith, C. D. et al 343-349

Hewer, W.see Rössler, W. et al 527-532

Hickling, Frederick W. andRodgers-Johnson, Pamela. The incidence of first contact schizophrenia in Jamaica 193-196

Hillier, Janissee Farmer, Anne et al 503-506

Hindmarch, I.see Kerr, J. S. et al (C) 413

Hoar, Amandasee Cole, Eleanor et al 770-776

Hollander, Dorissee Powell, Robin B.et al 765-769

Holloway, Franksee Phelan, Michael et al 589-595

Holmes, Jeremy. Supportive psychotherapy. The search for positive meanings (Review Article) 439-445

Hornig, Christopher D. and McNally, Richard J. Panic disorder and suicide attempt. A reanalysis of data from the epidemiologic catchment area study 76-79

House, A. see Gilbody, S. (C) 266

Howard, L. M. and Fahy, T. Psychosocial outcome of liver transplant (C) 267-268

Howes, S. see Goudsmit, E. M.(C) 818

Humayan, A. see Snaith, R. P. et al $99-103$

Humphreys, Martin S. see Davidson, Mark et al 545-548

Hunt, Neil see Silverstone, Trevor et al 58-60

Hunter, Davidsee Eagles, John M. et al469-472

Huppert, F. A.see Brayne, C. et al 255-262

Hurel, S. J.see Manchip, S. M.(C) 118

Ingle, Gordon T.seeLawrie, Stephen M. et al 202-210

Inoue, Shimpei see Tanaka, Shuichi et al 794-798

Isometsä, Erkki T.see Heikkinen, Martti E. et al 747-753

Ito, L. M.see de Araujo, L. A. et al 65-70

Ito, L. M. et al. Does imagined exposure to the consequences of not ritualising enhance live exposure for OCD? A controlled study. II. Effect on behaviouralv. subjective concordance of improvement 71-75

Janson, Helen see Buist, Anne 370-373

Jennison, Chris see Barker, Andrew et al 642-648

Jerusalem, F. see Maurer, I. et al (C) 551-552

Johnson-Sabine, Ericsee Cole, Eleanor et al 770-776

Johnstone, E. C. et al. Determinants of the extremes of outcome in schizophrenia 604-609

Johnstone, Eve C.see Davidson, Mark et al 545-548

Johnstone, Eve C.see Lawrie, Stephen M. et al 202-210
Johnstone, F. et al. The costs of psychotropic medication (C) 112-113

Jones, Gareth H. Informed consent in chronic schizophrenia? (Editorial) 565-568

Jones, Irene see Farmer, Anne et al 503-506

Jones, Peter see David, Anthony et al 621-628

Jones, Roysee Barker, Andrew et al 642-648

Jones, T. see Walker-Kinnear, M.(C) 550-551

Jönsson, B. and Bebbington, P. E. Economics of treatment of depression (Authors' reply) (C) 112

Jorm, A. F. see Forsell, Y. et al 61-64

Joughin, N. see Soomro, G. M. et al 385-389

Joyce, Peter R. see Sullivan, Patrick F. et al 679-682

Judge, R. see Oehrberg, S. et al 374-379

Kachaeva, M. Russian literature and psychiatry (Lecture) 403406

Kaliszer, Michael see Daly, Ian et al 463-468

Kalsi, Gursharan et al. Investigation by linkage analysis of the $\mathrm{XY}$ pseudoautosomal region in the genetic susceptibility to schizophrenia 390-393

Kamppinen, Matti see Karlsson, Hasse (Editorial) 434-438

Karlsson, Hasse andKamppinen, Matti. Biological psychiatry and reductionism. Empirical findings and philosophy (Editorial) 434-438

Karno, Marvin see Telles, Cynthia et al 473-479

Katschnig, Heinz et al. Long-term follow-up after a drug trial for panic disorder 487-494

Kay, Clifford R.seeGilchrist, Anne C. et al 243-248

Kendall, Briansee Cope, Helen et al 86-94

Kendler, Kenneth S. and Walsh, Dermot. Gender and schizophrenia. Results of an epidemiologically-based family study 184-192

Kendrick, Tony see Pullen, Ian (Comment) 38-40

Kent, L. S. W. and Laidlaw, J. D. D. Suspected congenital sertraline dependence $(C) 412-413$

Kerr, J. S. et al. Behavioural toxicities of antidepressants (C) 413

Kerwin, Robert W.see Lucey, James V.et al 629-634

King, D. J. et al. Antipsychotic drug-induced dysphoria 480 482

King, Elizabeth see Brown, Martin et al 448-45

King, Elizabeth A. see Thompson, Christopher et al 380-384

King, Michaelsee Cole, Eleanor et al 770-776

Kinsella, Anthonysee Waddington, John L. et al 41-44

Klemperer, F. The cultural context of hallucinations (C) 115116

Klerman, Gerald L. seeKatschnig, Heinz et al 487-494

Knapp, M. see McCrone, P. et al (Authors'reply)(C) 268-269

Knopp, M. V.see Schröder, J.et al 197-201

Kolaitis, G. see Kordoutis, P. et al (suppl. 28) 56-69

Kolaitis, G. see Perakis, A. et al (suppl. 28) 70-77

Kolaitis, G. see Tsiantis, J. et al (suppl. 28) 10-45, 46-55

Kolvin, I. Children in institutions (Editorial) 8-11

Kordoutis, P.see Perakis, A.et al (suppl. 28) 70-77

Kordoutis, P.see Tsiantis, J. et al (suppl. 28) 10-45, 46-55

Kordoutis, P. et al. Change in care staff's attitudes towards people with learning disabilities following intervention at the Leros PIKPA Asylum (suppl. 28) 56-69

Kranidioti, M.see Perakis, A.et al (suppl. 28) 70-77 
Krekorian, Haroutyonsee Wilkinson, Greg et al 26-37

Kunin, A. see Avnon, M. (C) 699

Laidlaw,J. D. D. see Kent, L.S. W.(C) 412-413

Lang, F. H.see Johnstone, E. C. et al 604-609

Larkin, Conallsee Waddington, John L. et al $41-44$

Launer, Michael. Clozapine, eating disorders and substance abuse. Obstacles to innovation in a peripheral hospital (Editorial) 431-433

Law, Samuel andWolfson, Christina. Validation of a French version of an informant-based questionnaire as a screening test for Alzheimer's disease 541-544

Lawrie, Stephen M. see Geddes, John R. 786-793

Lawrie, Stephen M. et al. Magnetic resonance imaging and single photon emission tomography in treatment-responsive and treatment-resistant schizophrenia 202-210

Leavey, Gerard see Cole, Eleanor et al 770-776

Lee, A.see Gregg, W. et al 812-817

Lee, Sing. The Chinese classification of mental disorders (C) $117-118$

Légeron, Patricksee Cottraux, Jean et al 635-641

Lester, M. andBlanchard, M. Late-life depressive disorder(C) 822

Lichtshein, G. and Fernandez, A.(C) 115

Liddle, P. F. see Frith, C. D. et al 343-349

Llewelyn, Meirion see Farmer, Anne et al 503-506

Loas, G. andBoyer, P. Scale for assessing hedonic tone (C) 551

Löffler, W.see Rössler, W. et al 527-532

Loftus, Lindasee Phelan, Michael et al 589-595

Lönnqvist, Jouko K. see Heikkinen, Martti E. et al 747-753

Lopez, Stevensee Telles, Cynthia et al 473-479

Loughrey, G.see Gregg, W. et al 812-817

Lowens, Ian see Haddock, Gillian et al 618-620

Lucas, R. A. see King, D. J. et al $480-482$

Lucey, James V.et al. Regional cerebral blood flow in obsessivecompulsive disordered patients at rest. Differential correlates with obsessive-compulsive and anxious-avoidant dimensions 629-634

Lumsden, J.see Watson, M. R.et al 514-521

Lynch, D.see Soomro, G. M. et al 385-389

McClelland, R. J.see Watson, M. R.et al 514-521

McCluskey, S. see Serfaty, M. A. et al (C) 410

McCormick, Rodney V. see DeSisto, Michael J. et al 331338, 338-342

McCreadie, Robin G. et al. The Nithsdale schizophrenia surveys. XIV: Plasma lipid peroxide and serum vitamin E levels in patients with and without tardive dyskinesia, and in normal subjects $610-617$

McCrone, P. et al. Costs of community psychiatric nurse teams (Authors'reply)(C) 268-269

McCrone, Paulsee Phelan, Michael et al 589-595

MacDonald, Elizabeth see McCreadie, Robin G. et al610 617

MacDonald, S. see Corrigan, F. M.et al (C) 412

McGilchrist, Iain and Cutting, John. Somatic delusions in schizophrenia and the affective psychoses 350-361

McGonigal, Gerard see Whalley, Lawrence J. et al 728-731

McGrath, John et al. Month of birth, hemisphere of birth and schizophrenia 783-785

McGuigan, S. M. The use of statistics in the British Journal of Psychiatry 683-688
McGuire, Ralph J. see Patience, Douglas A. et al 324-330

McKay, A. P. et al. Neuropsychological function in manicdepressive psychosis. Evidence for persistent deficits in patients with chronic, severe illness 51-57

McKeith, Ian G. et al. Lewy body dementia - diagnosis and treatment (Editorial) 709-717

McKenna, P.J. see McKay, A.P. et al 51-57

McLees, Sheila see Wilkinson, Greg et al 26-37

McNally, Richard J.seeHornig, Christopher D. 76-79

McPherson, Heathersee Silverstone, Trevor et al 58-60

McQuade, Cecilia A.see Whalley, Lawrence J.et al 728-731

McTavish, S. F. B. see Williamson, D. J. et al 238-242

Madigan, Cathysee Waddington, John L. et al 41-44

Maier, Michael. In vivo magnetic resonance spectroscopy. Applications in psychiatry (Review Article) 299-306

Maj, Mario see Galderisi, Silvana et al 394-398

Malhotra, Savita see Susser, Ezra et al 216-219

Malla, Ashok K. et al. Relationship between movement planning and psychopathology profiles in schizophrenia 211-215

Manchip, S. M. andHurel, S. J. Rhabdomyolysis due to mania (C) 118

Manniche, P. M. see Oehrberg, S. et al 374-379

Marchbanks, R. M. et al. Aspects of oxidative metabolism in schizophrenia (Editorial) 293-298

Marks, I. Statistical design, analysis and further correspondence (C) 270

Marks, I. Treatment of obsessive-compulsive disorder (C) 411-412

Marks, I. M. see de Araujo, L. A.et al 65-70

Marks, I. M.see Ito, L. M. et al 71-75

Marks, Isaac see Cromarty, Paul 399-402

Marks, Isaacsee Persaud, Rajendra45-50

Marks, Isaac M. see Lucey, James V. et al 629-634

Marlowe, J. see Snaith, R. P. et al (C) 411

Marshall, John C. andHalligan, Peter W. Method in madness (Commentary) 157-158

Marttunen, Mauri J.see Heikkinen, Martti E. et al 747-753

Mason, Peter et al. Characteristics of outcome in schizophrenia at 13 years $596-603$

Masterton, G. see O'Carroll, R. E. et al 95-98

Maurer, I. et al. Neuroleptic associated extrapyramidal symptoms(C) 551-552

Medley, I. see Gregg, W. et al 812-817

Medley, Ian see Mason, Peter et al 596-603

Mellers, John D. C. et al. Psychotic and depressive symptoms in Parkinson's disease. A study of the growth hormone response to apomorphine 522-526

Merskey, H. Multiple personality disorder and false memory syndrome (Author's reply) (C) 265-266

Merwe, P.van der see Eales, M.J.(C) 823-824

Mezey, G. C. Women's response to adversity (C) 266

Micciolo, Rocco see Tansella, Michele et al 220-227

Michael, Albert et al. Morbid jealousy in alcoholism 668-672

Middleton, E. M. see Whitefield, L. et al (C) 825-826

Mino, Yoshiosee Tanaka, Shuichi et al 794-798

Mintz, Jimsee Telles, Cynthia et al 473-479

Mirza, K. A. H. see Michael, Albert et al 668-672

Mirza, Sudeshni see Michael, Albert et al 668-672

Mobayed, M. andBaynes, D. Life events and dementia (C) 407408

Möller, H.-J. see Maurer, I. et al (C) 551-552 
Moncrieff, J.Lithium revisited. A re-examination of the placebocontrolled trials of lithium prophylaxis in manic-depressive disorder (Editorial) 569-573

Moriarty, John et al. Brain perfusion abnormalities in Gilles de la Tourette's syndrome 249-254

Morley, S. see Snaith, R. P. et al 99-103

Mortensen, P. B. et al. Obstetric complications in schizophrenia (C) 695-696

Moss, Steve andPatel, Pradip. Psychiatric symptoms associated with dementia in older people with learning disability 663 667

Mucci, Armidasee Galderisi, Silvana et al 394-398

Mulcrone,J.see Marchbanks, R. M. et al (Editorial) 293-298

Munitz, Hanan see Weiss, David et al 483-486

Murphy, Patricesee Kalsi, Gursharan et al 390-393

Murray, C. see O'Carroll, R. E. et al 659-662

Murray, V. Laryngeal dystonia (C) 698-699

Naidu, Kaliprasad P see Lawrie, Stephen M. et al 202-210

Najman, Jackob M. see Vance, John C. et al 806-811

Nakdimen, K.A.Multiple personality disorder and false memory syndrome (C) 264

Neal, Leigh A. see Busuttil, Walter et al 495-502

Norman, Ross M. G.see Malla, Ashok K. et al 211-215

Norrman, Jennie et al. Apolipoprotein E genotype and its effect on duration and severity of early and late onset Alzheimer's disease 533-536

North, Clive et al. Family functioning in adolescent anorexia nervosa 673-678

Note, Ivan-Druonsee Cottraux, Jean et al 635-641

O'Callaghan, Eadbhardsee Waddington, John L. et al 41-44 $\mathbf{O}^{\prime}$ Carroll, R. E. et al. Further evidence that reading ability is not preserved in Alzheimer's disease 659-662

O'Carroll, R. E. et al. The neuropsychiatric sequelae of mercury poisoning. The mad hatter's disease revisited 95-98

O'Carroll, Ronan E.see Lawrie, Stephen M. et al 202-210

O'Connor, D. W. see Brayne, C. et al 255-262

Oehrberg, S. et al. Paroxetine in the treatment of panic disorder. A randomised, double-blind, placebo-controlled study 374 379

O'Hanlon, J. F. and Freeman, H. Behavioural toxicities of antidepressants (Authors' reply) (C) 413-414

O'Hare, Tom and Creed, Francis. Life events and miscarriage 799-805

Ohrstrom, J. K. see Oehrberg, S. et al 374-379

Ohta, Mikio see Abe, Kazuhiko 507-513

Ojen, R. L. van and Tilburg, W. van. Late-life depressive disorder (Authors' reply)(C) 822-823

Oldehinkel, A. J. and Giel, R. Time trends in the care-based incidence of schizophrenia 777-782

Owens, D. G. C. see Johnstone, E. C. et al 604-609

Owens, D. W. Economics of treatment of depression (C) 112

Oyebode, F. A 'PC' model of the mind (C) 693-694

Oyebode, Femisee Ballard, Cliveet al 537-540

Papanikolopoulou, P.see Kordoutis, P.et al (suppl. 28) 56-69 Park, S. B. G. see Williamson, D. J. et al 238-242

Patel, Pradip see Moss, Steve 663-667
Paterson, John R.see McCreadie, Robin G. et al610-617

Patience, Douglas A. et al. The Edinburgh Primary Care Depression Study: personality disorder and outcome 324330

Paykel, E. S. see Brayne, C. et al 255-262

Paz, Georgesee Telles, Cynthia et al 473-479

Pearce, Jane et al. Psychological and sexual symptoms associated with the menopause and the effects of hormone replacement therapy (Review Article) 163-173

Pearson, Veronica. Population policy and eugenics in China (Editorial) 1-4

Pemberton, Michael see McGrath, John et al 783-785

Perakis, A. see Kordoutis, P. et al (suppl. 28) 56-69

Perakis, A. see Tsiantis, J. et al (suppl. 28) 10-45, 46-55

Perakis, A. et al. Mortality among institutionalised people with learning disabilities in Greece: a 30-year survey at the Leros PIKPA Asylum (suppl. 28) 70-77

Pernet, Amanda see Cope, Helenet al 86-94

Persaud, Rajendra andMarks, Isaac. A pilot study of exposure control of chronic auditory hallucinations in schizophrenia 45-50

Petursson, Hannessee Kalsi, Gursharan et al 390-393

Phelan, M. see Crimlisk, H.(C) 116-117

Phelan, Michael et al. The Camberwell Assessment of Need the validity and reliability of an instrument to assess the needs of people with severe mental illness 589-595

Piccinelli, Marco see Wilkinson, Greg et al 26-37

Pilowsky, Lyn S.see Lucey, James V. et al 629-634

Powell, Robin B. et al. Crisis in admission beds. A four-year survey of the bed state of Greater London's acute psychiatric units 765-769

Power, K.G. see Sharp, D. M.et al (C) 820-821

Prentice, N.see O'Carroll, R. E. et al 659-662

Price, D. J. E. see Snaith, R. P. et al (C) 411

Pullen, Ian and Kendrick, Tony. Peer commentaries on 'An evaluation of community-based psychiatric care for people with treated long-term mental illness' (Comment) 38-40

Quinn, Niall P. see Mellers, John D. C.et al 522-526

Quinton, David et al. A 15 to 20 year follow-up of adult psychiatric patients. Psychiatric disorder and social functioning 315-323

Rabinowitz, Jonathan see Avnon, Moshe 760-764

Radwan, Margaretsee Weiss, David et al 483-486

Raheja, Sunil K.see Thompson, Christopher et al 380-384

Ratan, D. A. and Friedman, T. Antidepressants in pregnancy and breastfeeding (C) 824

Read, Timsee Kalsi, Gursharan et al 390-393

Redmond, Oonaghsee Waddington, John L. et al 41-44

Reid, Andrew H. andBallinger, Brian R. Behaviour symptoms among severely and profoundly mentally retarded patients. A 16 to 18 year follow-up study $452-455$

Reveley, A. see Taylor, D.et al (C) 409-410

Reynolds, G. P. see Corrigan, F. M. et al (C) 412

Richards, Hilary see Goodman, Robert 362-369

Rickard, I. see Johnstone, F. et al (C) 112-113

Rindin, L. andTakei, N.Obstetric complications in schizophrenia (C) 694-695

Rimmington, J. EwenseeLawrie, Stephen M. et al 202-210 
Roberts, Jane. Lone mothers and their children (Editorial) 159-162

Robertson, M. M.see Whitefield, L. et al (C) 825-826

Robertson, Margaret F. and Tyrer, Peter. 'Supportive psychotherapy' (Peer Review) 446-447

Robertson, Mary M. see Moriarty, Johnet al 249-254

Rodgers-Johnson, Pamelasee Hickling, Frederick W. 193196

Rogers, Andrew C.seeLawrie, Stephen M. et al 202-210

Rollin, Henry. Malingering and miracles (A hundred years ago) 700

Rollin, Henry. Society for the Study of Inebriety ( $A$ hundred years ago) 414

Rollin, Henry. The alleged increase of insanity ( $A$ hundred years ago) 826

Rollin, Henry. The Association of Workers in Asylums for the Insane. By Fletcher Beach (A hundred years ago) 554

Rollin, Henry. The New Inebriates Bill (A hundred years ago) 270

Rollin, Henry. The simulation of death by fakirs ( $A$ hundred years ago) 119

Rollins, John see Busuttil, Walter et al 495-502

Romans, Sarahsee Silverstone, Trevor et al 58-60

Ron, Maria A.see Mellers, John D. C.et al 522-526

Ross, C. A. Multiple personality disorder and false memory syndrome (C) 263-264

Rössler, W. et al. Excess mortality among elderly psychiatric in-patients with organic mental disorder 527-532

Roth, Sir Martin see Katschnig, Heinz et al 487-494

Rutherford, W. H. see Watson, M.R. et al 514-521

Rutter, Michaelsee Quinton, Davidet al 315-323

Sacker, A. see Done, D. J. (Authors' reply) (C) 696-697

Santosh, Celestine G. see Lawrie, Stephen M. et al 202-210

Sattel, Heribertsee Förstl, Hanset al 739-746

Schad, L. R.see Schröder, J. et al 197-201

Schmitz, Bettinasee Moriarty, Johnet al 249-254

Schröder, J. et al. Sensorimotor cortex and supplementary motor area changes in schizophrenia. A study with functional magnetic resonance imaging 197-201

Scott, A. I. F. ECT seizure threshold (C) 117

Scott, A. I. F. Seizure threshold in bilateral and unilateral ECT (Author's reply)(C) 822

Scott, Allan I. F.see Patience, Douglas A. et al 324-330

Scott, Jan. Psychological treatments for depression. An update (Editorial) 289-292

Scott, Jan. Psychotherapy for bipolar disorder (Review Article) $581-588$

Scott, M. see Wilson, K. C. M. et al 653-658

Scull, D. A. and Trimble, M. R. Mania precipitated by carbamazepine withdrawal(C) 698

Serfaty, M. A. et al. Extreme suicidality following serotonin syndrome (C) 410

Severin, B. see Oehrberg, S. et al 374-379

Sham, Paksee Hand, David(Commentary) 689-691

Shanks, M. F. Chronic fatigue syndrome (Author's reply) (C) 550

Shapleske, J. see McKay, A. P. et al 51-57

Sharma, Tonmoysee Kalsi, Gursharan et al 390-393

Sharp, D. M. et al. Five group comparisons of treatments for anxiety disorders (C) 820-821
Shepherd, Jonathan P. see Bisson, Jonathan I. (Editorial) 718-720

Shepherd, Michael. Psychiatry and philosophy (Editorial) 287-288

Shepherd, Michael. Two faces of Emil Kraepelin 174-183

Sikdar, S. Self-measure of neuroleptic side-effects (C) 113-114

Silbersweig, D. see Frith, C. D. et al 343-349

Silverstone, Trevor $e t a l$. Is there a seasonal pattern of relapse in bipolar affective disorder? A dual northern and southern hemisphere cohort study 58-60

Simkin, Sue et al. Media influence on parasuicide. A study of the effects of a television drama portrayal of paracetamol self-poisoning 754-759

Simpson, R. J. see Sharp, D. M. et al (C) 820-821

Slade, Mike see Phelan, Michael et al 589-595

Smith, Andrew see Farmer, Anneet al 503-506

Snaith, R. P. et al. A scale for the assessment of hedonic tone. The Snaith-Hamilton Pleasure Scale 99-103

Snaith, R. P. et al. Psychosurgery for obsessional disorder (C) 411

Soegaard, J.see Oehrberg, S. et al 374-379

Solyom, Carol see Katschnig, Heinz et al 487-494

Soomro, G. M. et al. Anorexia nervosa in 'non-white' populations 385-389

Stack, John P.see Waddington, John L. et al 41-44

Starr, John M. see Whalley, Lawrence J. et al 732-738

St Clair, David see Norrman, Jennie et al 533-536

Stefan, Martin D. andCatalán, José. Psychiatric patients and HIV infection: a new population at risk? (Review Article) 721-727

Stolk, Jon M.see Katschnig, Heinz et al 487-494

Strathdee, Geraldinesee Phelan, Michael et al 589-595

Sullivan, Patrick F. et al. The significance of a history of childhood sexual abuse in bulimia nervosa 679-682

Susser, Ezra et al. Delineation of acute and transient psychotic disorders in a developing country setting 216-219

Swingler, Robert see Whalley, Lawrence J. et al 728-731

Takei, N. see Lucey, James V. et al 629-634

Takei, N. see Rifkin, L. (C) 694-695

Tanaka, Shuichi et al. Expressed emotion and the course of schizophrenia in Japan 794-798

Tansella, Michele et al. Episodes of care for first-ever psychiatric patients. A long-term case register evaluation in a mainly urban area 220-227

Tarbuck, A. F.see McKay, A.P.et al 51-57

Tarrier, Nicholas see Haddock, Gillian et al 618-620

Taylor, D. et al. Clozapine-induced hypotension treated with moclobemide and Bovril (C) 409-410

Taylor, David. Selective serotonin reuptake inhibitors and tricyclic antidepressants in combination. Interactions and therapeutic uses (Review Article) 575-580

Telles, Cynthia et al. Immigrant families coping with schizophrenia. Behavioural family intervention $v$. case management with a low-income Spanish-speaking population 473-479

Thearle, M. John see Vance, John C. et al 806-811

Thomas, Brenda M.see Whalley, Lawrence J. et al 728-731, 732-738

Thompson, C. Economics of treatment of depression (C) 112 
Thompson, Christopher et al. A follow-up study of seasonal affective disorder $380-384$

Thorburn, R. Dystonia and neuroleptic medication (C) 114

Thornicroft, Grahamsee Phelan, Michael et al 589-595

Tilhonen, J. et al. Homicidal behaviour and mental disorders (C) 821

Tilburg, W. van see Ojen, R. L. van(Authors'reply)(C) 822 823

Tobiansky, Robert I. see Powell, Robin B. et al 765-769

Tomenson, Barbara see Baldwin, R. C. 649-652

Tran, Duong see Soomro, G. M.et al 385-389

Trigwell, P. see Snaith, R. P. et al 99-103

Trimble, M.R. see Scull, D. A. (C) 698

Trimble, Michael R.see Moriarty, John et al 249-254

Tsiantis, J. see Kordoutis, P. et al (suppl. 28) 56-69

Tsiantis, J. see Perakis, A. et al (suppl. 28) 70-77

Tsiantis, J. et al. The Leros PIKPA Asylum. Deinstitutionalisation and rehabilitation project (suppl. 28) 10-45

Tsiantis, J. et al. The psychosocial dynamics of change at Leros PIKPA Asylum (suppl. 28) 46-55

Tsiantis, John. Conclusions (suppl. 28) 78-79

Tsiantis, John. Introduction (suppl. 28) 7-9

Tucker, Douglas see Telles, Cynthin et al 473-479

Turnbull, Gordon J.see Busuttil, Walter et al 495-502

Tyrer, Peter see Robertson, Margaret F.(Peer Review) 446447

Uzych,L.Eugenics (C) 697-698

Van Beck, M.see O'Carroll, R. E. et al 659-662

Vance, John C. et al. Gender differences in parental psychological distress following perinatal death or Sudden Infant Death Syndrome 806-811

van Os, Jim see David, Anthony et al 621-628

Varma, Vijoy K. see Susser, Ezra et al 216-219

Vithayathil, Empee see Michael, Albert et al 668-672

Vize, Christine M. and Cooper, Peter J. Sexual abuse in patients with eating disorder, patients with depression, and normal controls. A comparative study 80-85

Volavka, J. Lead-in placebo washout period (C) 694

von Strauss, E. see Forsell, Y.et al 61-64

Waddington, John L. et al. Tardive dyskinesia in schizophrenia. Relationship to minor physical anomalies, frontal lobe dysfunction and cerebral structure on magnetic resonance imaging 41-44

Walker-Kinnear, M. andJones, T. Blu-Tack-a novel substance of abuse (C) 550-551

Wallace, D. see Curran, S. (C) 821-822

Walsh, Dermot see Kendler, Kenneth S. 184-192

Watson, M. R. et al. The post-concussional state: neurophysiological aspects 514-521

Webb, Marcus see Daly, Ian et al 463-468

Weiss, David et al. Cyproheptadine treatment in neurolepticinduced akathisia 483-486

Weissman, M. M.Comorbidity and suicide risk (C) 819-820

Weizman, Abraham seeWeiss, David et al 483-486

Welham, Joy see McGrath, John et al 783-785

Wenz, F. see Schroder, J. et al 197-201
West, Adrian G.see Busuttil, Walter et al 495-502

Whalley, Lawrence J. et al. Epidemiology of presenile Alzheimer's disease in Scotland (1974-88)

I. Non-random geographical variation 728-731

II. Exposures to possible risk factors 732-738

Whatley,S.A. see Marchbanks, R. M. et al (Editorial) 293-298

Whitefield, L. et al. Visual fields in Gilles de la Tourette syndrome (C) 825-826

Whitehead, Linda see Simkin, Sue et al 754-759

Wilcock, Gordon see Ballard, Clive et al 537-540

Wilcock, Gordon K. see McKeith, Ian G. et al (Editorial) 709-717

Wiles, Davidsee McCreadie, Robin G. et al610-617

Wilkinson, Greg et al. An evaluation of community-based psychiatric care for people with treated long-term mental illness 26-37

Williamson, D. J. et al. Effect of valine on 5-HT-mediated prolactin release in healthy volunteers, and on mood in remitted depressed patients 238-242

Wilson, K. C. M. et al. Long-term effects of cognitivebehavioural therapy and lithium therapy on depression in the elderly 653-658

Winblad, B.see Forsell, Y.et al 61-64

Wolfenden, Melanie see Haddock, Gillian et al 61 8-620

Wolfson, Christina see Law, Samuel 541-544

Wykes, Til see Phelan, Michael et al 589-595

Yates, Celiasee Norrman, Jennie et al 533-536

Zacharias, V. see Tsiantis, J. et al (suppl. 28) 10-45

Zemishlany, Zvisee Weiss, David et al 483-486

Zerfaß, Rainer see Förstl, Hans et al 739-746

Zierz, S. see Maurer, I. et al (C) 551-552

\section{PART III.BOOKREVIEWS ANDREVIEWOFBOOKS}

Ammerman, Robert andHersen, Michael (eds). Handbook of child behaviour therapy - in the psychiatric setting (Ian Berg) 428

Andreasen, Nancy (ed.). Teaching and learning about schizophrenia: a WPA educational programme (Robert Howard) 559

Archer, John (ed.). Male violence (David Price)(R of B) 137 140

Arendt, Josephine. Melatonin and the mammalian pineal gland (Christopher Thompson) 419

Armstrong, David. Outline of sociology as applied to medicine (4th edn) (D. W. Millard) 424

Bakker, F. C., Whiting, H. T. A. and van der Brug, H. Sport psychology: concepts and applications (Sidney Crown) (R of B) 140-142

Barker, Ann F. Arson: a review of the psychiatric literature (Herschel Prins) 425 
Barnes, Thomas R. E. and Nelson, Hazel E. (eds). The assessment of psychoses: a practical handbook (Supriy Kavi) 702

Benedetti, Gaetano and Furlan, Pier Maria (eds). The psychotherapy of schizophrenia. Effective clinical approaches - controversies, critiques and recommendations (Murray Cox)(RofB) 126-129

Benjamin, S., House, A. and Jenkins, P. (eds). Liaison psychiatry - defining needs and planning services (Christopher Bass) 424-425

Birchwood, Max and Tarrier, Nicholas (eds). Psychological management of schizophrenia (Douglas Turkington) 425

Birtchnell, John. How humans relate: a new interpersonal theory (Mike Startup) (R of B) 832-833

Bloch, Sidney, Hafner, Julian, Harari, Edwin andSzmukler, George I. The family in clinical psychiatry (Christopher Dare) 274

Blom-Cooper, Louis, Hally, Helen andMurphy, Elaine. The falling shadow: one patient's mental health care (Tony Maden)(R of B) 827-828

Bond, Tim. Standards and ethics for counselling in action (Nigel Beail)273-274

Brothers, Barbara Jo (ed.). Couples therapy, multiple perspectives. In search of universal threads (Sasha Brookes) (RofB) 135-136

Burleigh, Michael. Death and deliverance. Euthanasia in Germany, 1900 to 1945 (Henry R. Rollin) 145

Challis, D., Darton, R., Johnson, L. et al. Care management and health care of older people (Rosie Jenkins and David Jolley) 558-559

Chick, J. and Cantwell, R. (eds). Seminars in alcohol and drug misuse (Brian D. Hore) 420-421

Chiu, E. and Ames, D. (eds). Functional psychiatric disorders of the elderly (Joe Herzberg) 427

Conrad, Kendon J., Hultman, Cheryl, I. andLyons, John S. (eds). Treatment of the chemically dependent homeless. Theory and implementation in fourteen American projects (Siobhan Jeffreys) 417-418

Cooper, John E. (ed.). Pocket guide to the ICD-10 classification of mental and behavioural disorders (Richard Caplan) 704 705

Cornett, Carlton. Reclaiming the authentic self. Dynamic psychotherapy with gay men (Michael King) 845-846

Costello, Charles G. (ed.). Symptoms of schizophrenia(David Geaney) 283

Cox, John andHolden, Jeni (eds). Perinatal psychiatry: use and misuse of the Edinburgh Postnatal Depression Scale (Roch Cantwell) 560

Crook, Paul. Darwinism, war and history (David Price)(R of B) 137-140

Cutler, NealR,,Sramek, JohnJ. andVerofi, Amy E.Alzheimer's disease: optimizing drug development strategies (Tom Dening) 280-281

Dalton, Richard and Forman, Marc A. Psychiatric hospitalisation of school-age children(S. Gowers)(R ofB) 837-838

Dansky, Steven F. Now dare everything: tales of HIV-related psychotherapy (Bernard Ratigan) 418
Davy, Graham andTallis, Frank(eds). Worrying. Perspectives on therapy, assessment and treatment (P. Gilbert) 278

Denmark, J. C. Deafness and mental health (Peter Hindley) 426-427

Dryden, Windy and Feltham, Colin. Counselling and psychotherapy. A consumer's guide (Michael King) 845

Dryden, Windy and Feltham, Colin. Developing counsellor training(Terry Birchmore)423-424

Dryden, Windy andFeltham, Colin. Developing the practice of counselling (Terry Birchmore) 423-424

Edwards, G. andPeters, T.J. (eds). British Medical Bulletin: alcohol and alcohol problems (Prakash Naik) 702

Erskine, Aleda and Judd, Dorothy (eds). The imaginative body: psychodynamic therapy in health care (Jane Blunden) 275

Feder, Stuart et al (eds). Psychoanalytic explorations in music (Second Series) (G. S. Feggetter) (R of B) 829-830

Feldman, Marc D., Ford, Charles V. and Reinhold, Toni. Patient or pretender - inside the strange world of factitious disorders (J. Smith)(R of B) 122-124

Feltham, Colin and Dryden, Windy. Developing counsellor supervision(Terry Birchmore) 423-424

Frazer, Alan, Molinoff, Perry and Winokur, Andrew (eds). Biological bases of brain function and disease (Simon Fleminger) 144

Freeman, DavidS. Family therapy with couples: the family-oforigin approach (Sasha Brookes) (R of B) 135-136

Fritz, Gregory K., Mattson, Richard E., Nurcombe, Barry et al. Child and adolescent mental health consultation in hospitals, schools and courts (Carol Sheldrick) 283-284

Fuller, Ray (ed.). Seven pioneers of psychology (Caroline Selai) 415

Gardner, Richard. Story-telling in psychotherapy with children (Linda Winkley) ( $R$ of $B$ ) 132-135

Garety, Philippa A. and Hemsley, David R. Delusions: investigations into the psychology of delusional reasoning (Robert Cawley) 706

Gartrell, Nanette K.(ed.). Bringing ethics alive: feminist ethics in psychotherapy practice (Susan Davison) 561

Gazzaniga, Michael. Nature's mind - the biological roots of thinking, emotions, sexuality, language and intelligence (David Price)(R of B) 137-140

Ghuman, HarinderS. andSarles, Richard M. (eds). Handbook of adolescent in-patient psychiatric treatment(S. Gowers)(R ofB) 837-838

Gill, Merton M. Psychoanalysis in transition. A personal view (Richard Carvalho) 418-419

Gillham, Bill. The facts about child physical abuse (Kevin Browne) 281

Gilroy, Andrea and Lee, Colin (eds). Art and music: therapy and research (Graeme Feggetter) 421-422

Giovacchini, Peter L. Borderline patients, the psychosomatic focus, and the therapeutic process (Julian M. Stern) 705

Gonsiorek, J. Breach of trust - sexual exploitation by health care professionals and clergy (Eileen Vizard) 703

Graham, Philip andHughes, Carol. So young, so sad, so listen (Jane Morris, Julia Burnside and J. Pearce)(R of B) 836-837 
Haggerty, Robert J., Sherrod, Lonnie R., Garmezy, Norman et al (eds). Stress, risk, and resilience in children and adolescents. Processes, mechanisms and interventions (David Cottrell) 846

Heinemann, Allen (ed.). Substance abuse and physical disabilities (Judith Myles) 281-282

Hersen, Michael and Turner, Samuel N. (eds). Diagnostic interviewing (2nd edn)(Frances Klemperer)416-417

Hollander, E. andStein, D. (eds). Impulsivity and aggression (Ekkehart F. A. Staufenberg) 702-703

Hollander, E., Zohar, J., Msarazziti, D. andOlivier, B. (eds). Current insights in obsessive compulsive disorder (Isaac Marks) 415-416

Horvath, Adam O. andGreenberg, LeslieS. (eds). The working alliance: theory, research and practice (Charles Lund) 422

Huppert, Felicia A., Brayne, Carol and O'Connor, Daniel W. (eds). Dementia and normal ageing (Ola Junaid) 276-277

Hyman, Steven E. and Nestler, Eric J. The molecular foundations of psychiatry (R. W. Kerwin) (R of B) 130 132

Jackson, Murray and Williams, Paul. Unimaginable storms a search for meaning in psychosis(Brian V.Martindale) 143144

Janssen, Paul. Psychoanalytic therapy in the hospital setting (Jeffrey Roberts) 274-275

Joffe, R. T. and Calabrese, J. R. (eds). Anticonvulsants in mood disorders (B. E. Leonard) 558

Jones, Gemma andMiesen, Bere(eds). Care-giving in dementia (Colm Cooney)(R of B) 121-122

Jones, Graham andHardy, Lew (eds). Stress and performance in sport (Sidney Crown) (R of B) 140-142

Jones, Kathleen. Asylums and after. A revised history of the mental health services: from the early 18 th century to the 1900 s (Henry R. Rollin)(R ofB) 828-829

Jones, Richard (ed.). Mental Health Act manual (4th edn) (Edward Gordon) 427

Jones, Steve. The language of the genes (Isaac Marks) 271

Kaplan, H. I., Sadock, B.J.andGrebb,J. A. (eds). Kaplan and Sadock's synopsis of psychiatry. Behavioural sciences. Clinical psychiatry seventh edition (Greg Wilkinson) ( $R$ of B) $841-843$

Kaplan, Harold I. andSadock, Benjamin J. Study guide and self-examination review for Kaplan and Sadock's synopsis of psychiatry (5th edn) (David Newby) 706

Kaplan, Harold I., Sadock, Benjamin J.andGrebb, Jack A. (eds). Kaplan and Sadock's synopsis of psychiatry (7th edn) (Janice Morgan) 284

Katz Olson, Laura (ed.). The graying of the world. Who will care for the frail elderly? (Tom Arie) 146

Kavaler-Adler, Susan. The compulsion to create: a psychoanalytic study of women artists (Murray Cox) ( $R$ of B) 840

Kendell, R. E. andZealley,A.K. (eds). Companion topsychiatric studies fifth edition (Greg Wilkinson)(R of B) 841-843

Kerkof, Ad et al (eds). Attempted suicide in Europe (Ian O'Donnell) 701
King, Neville, Hamilton, David and Ollendick, Thomas. Children's phobias - a behavioural perspective (R. C. Harrington) 417

Kingdon, David and Turkington, Douglas. Cognitivebehavioural therapy of schizophrenia (Sara Davies) 277

Kirschner, Howard (ed.). Handbook of neurological speech and language disorders (Michael R. Trimble) 701

Knell, Susan. Behavioural play therapy (Linda Winkley)(R of B) $132-135$

Langone, Michael D.(ed.). Recovery from cults(Michael King) (R ofB) 129-130

Langs, Robert. Clinical practice and the architecture of the mind (Stephen Gladwell) 704

Lask, Bryan and Bryant-Waugh, Rachel. Childhood onset anorexia nervosa and related eating disorders(Simon Gowers) 560

Levin, Enid, Moriarty, Joand Gorbach, Peter. Better for the break (Susan F. Mitchell) 561

Lewis, C. E., O'Sullivan, C. and Barraclough, J. (eds). The psychoimmunology of cancer: mind and body in the fight for survival? (Lousie Howard and Anthony David)(R of B) 124 126

Lichtenberg, Peter. A guide to psychological practice in geriatric long-term care (Colm Cooney) (R of B) 121-122

Lindsay, S. J. E. and Powell, G. F. (eds). The handbook of clinical adult psychology second edition (Greg Wilkinson) (RofB) 841-843

Lovell, Richard. Churchill's doctor: a biography of Lord Moran (John Crammer)(R of B) 831-832

McConnell, $H$. andBianchine, J. (eds). Cerebrospinal fluid in neurology and psychiatry (Walter J. Muir) 145-146

McGuire, F., Boyd, R. andJames, A.. Therapeutic humour with the elderly (Alistair Burns) (R of B) 120-121

Mezey, Alex. Muse in torment: the psychopathology of creative writing (Felix Post)(R of B) 838-839

Miller, Edgar andMorris, Robin. The psychology of dementia (M.P. Nowers) 144

Miller, Lawrence. Psychotherapy of the brain-injured patient (Murray Cox)(R of B) 126-129

Miller, Norman S. (ed.). Comorbidity of addictive and psychiatric disorders (Jeanette Smith) 282-283

Mitchell, Rie Rodgers and Friedman, Harriet S. Sandplay: past, present and future (Linda Winkley) (R of B) 132-135

Miziker Gonet, Marlene. Counselling the adolescent substance abuser(Simon Gowers) 282

Moligliano Nissim, L. andRobutti, A. (eds). Shared experience - the psychoanalytic dialogue (M. Fitzgerald) 276

Money, John. The Kaspar Hauser syndrome of "psychosocial dwarfism". Deficient statual, intellectual and social growth induced by child abuse (Dora Black) (R of B) 834

Morgan, Gethin and Butler, Stuart (eds). Seminars in basic neurosciences (R. W. Kerwin) (R of B) 130-132

Morris, Peter and Gruneberg, Michael (eds). Theoretical aspects of memory (2nd edn) (Ian M. L. Hunter) 272

Morrison, Tony, Erooga, Marcus and Beckett, Richard C. (eds). Sexual offending against children(D. J. West)(R of B) 835-836 
Mrazek, P. J. and Haggerty, R. J. (eds). Reducing risks for mental disorders: frontiers for preventive intervention research (Jan Scott) 275-276

Newton, Jennifer. Preventing mental illness in practice (Laura Head) 416

Obholzer, A. and Roberts, V. Z. (eds). The unconscious at work: individual and organizational stress in the human services (Stephen P. Reilly) 428

Oldham, John M. and Bone, Stanley. Paranoia: new psychoanalytic perspectives (P. J. Shoenberg) 421

Oldham, John M. and Riba, Michelle B. (eds). Review of psychiatry(Volume 13)(Simon Groves) 703-704

Ostwald, Peter andZegans, Leonard (eds). The pleasures and perils of genius: mostly Mozart(G. S. Feggetter)(R of B) 829830

Owen, Frank and Itzhaki, Ruth (eds). Molecular and cell biology of neuropsychiatric diseases (R. W. Kerwin) (R of B) $130-132$

Pitt, Brice with illustrations byMel Calman. Down with gloom! (Sarah Bedell) 426

Pollock, George (ed.). How psychiatrists look at ageing (Vol. 2)(Rebecca Eastley)279-280

Pollock, George (ed.). Pivotal papers on identification(Andrew Clark) 562

Prendergast, William E. The merry-go-round of sexual abuse. Identifying and treating survivors (Michael King) (R of B) 833-834

Pullen, Ian, Wilkinson, Greg, Wright, Alastair and Pereira Gray, Denis (eds). Psychiatry and general practice today (Michael Modell) 272-273

Romme, Marius andEscher, Sandra. Accepting voices: a new analysis of the experience of hearing voices outside the illness model (Max Birchwood) ( $R$ of B) 843-844

Ross, Colin A. The Osiris complex - case studies in multiple personality disorder (Peter Tyrer) (R of B) 830

Ruszczynski, Stanley (ed.). Psychotherapy with couples(Sasha Brookes)(R of B) 135-136

Schopler, Eric and Mesibov, Gary B. (eds). Learning and cognition in autism (Andrew H. Reid) 557-558

Seraganian, Peter (ed.). Exercise psychology: the influence of physical exercise on psychological processes(Sidney Crown) (R of B) 140-142
Shader, Richard I. (ed.). Manual of psychiatric therapeutics (2nd edn) (Hayley Richards) 278

Shepherd, Jonathan (ed.). Violence in health care. A practical guide to coping with violence and caring for victims (Arden R. Tomison) 280

Sims, Andrew and Owens, David. Psychiatry (6th Edn) (Kurt Schapira) 277-278

Solity, Jonathan andBickler, Graham (eds). Support services -issues for education, health and social service professionals (Frank Holloway) 279

Solomon, Zahava. Combat stress reaction-the enduring toll of war(David Price) (R of B) 137-140

Steketee, Gail S. Treatment of obsessive compulsive disorder (Hilary Warwick) 559-560

Stewart, Donna E. andStotland, Nada L.(eds). Psychological aspects of women's health care: the interface between psychiatry and obstetrics and gynaecology (Anna Higgitt) 557

Strang, J. and Gossop, M. (eds). Heroin and drug policy: the British system (Spencer Madden) 419-420

Strean, Herbert (ed.). The use of humor in psychotherapy (John Birtchnell) 279

Tantam, Digby and Birchwood, Max (eds). Seminars in psychology and the social sciences (A. C. Brown) 272

Tyrer, Peter andSteinberg, Derek. Models for mental disorder: conceptual models in psychiatry (2ndedn)(K.W.M. Fulford) 143

Varma, Ved (ed.). Coping with unhappy children (Sandra Duke) 422

Vellas, B. J. et al (eds). Dementia and cognitive impairments (John Kellett) 561-562

Willows, Dale M., Kruk, Richard S.andCorcos, Evelyne(eds). Visual processes in reading and reading disabilities (Ann Craft) 281

Woodside, D. Blake, Shekter-Wolfson, Lorie F., Brandes, JackS. andLackstrom, Jan B. Eating disorders and marriage, the couple in focus (Sasha Brookes) ( $R$ of B) 135-136

Zeanah, Charles (ed.). Handbook of infant mental health (Michael Berger) 425-426 
A supplement to the British Journal of Psychiatry

Printed in Great Brituin by Henry Ling Ltd., at the Dorset Press, Dorchester, Dorset

\subsection{7

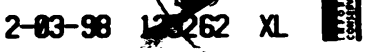




\section{Give someone with epilepsy a future to look forward to}

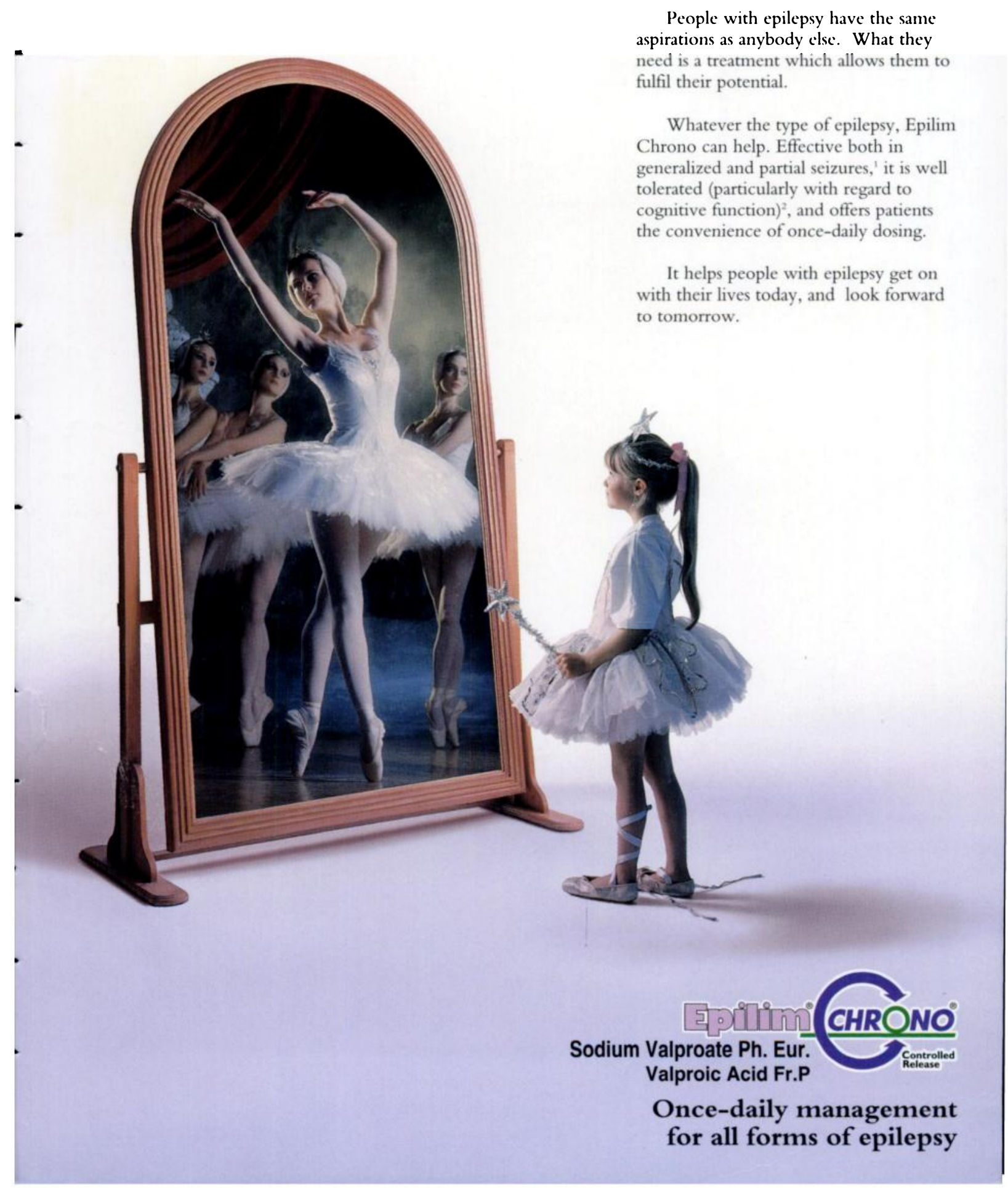




\section{Leadership isn't given. It's earned.}
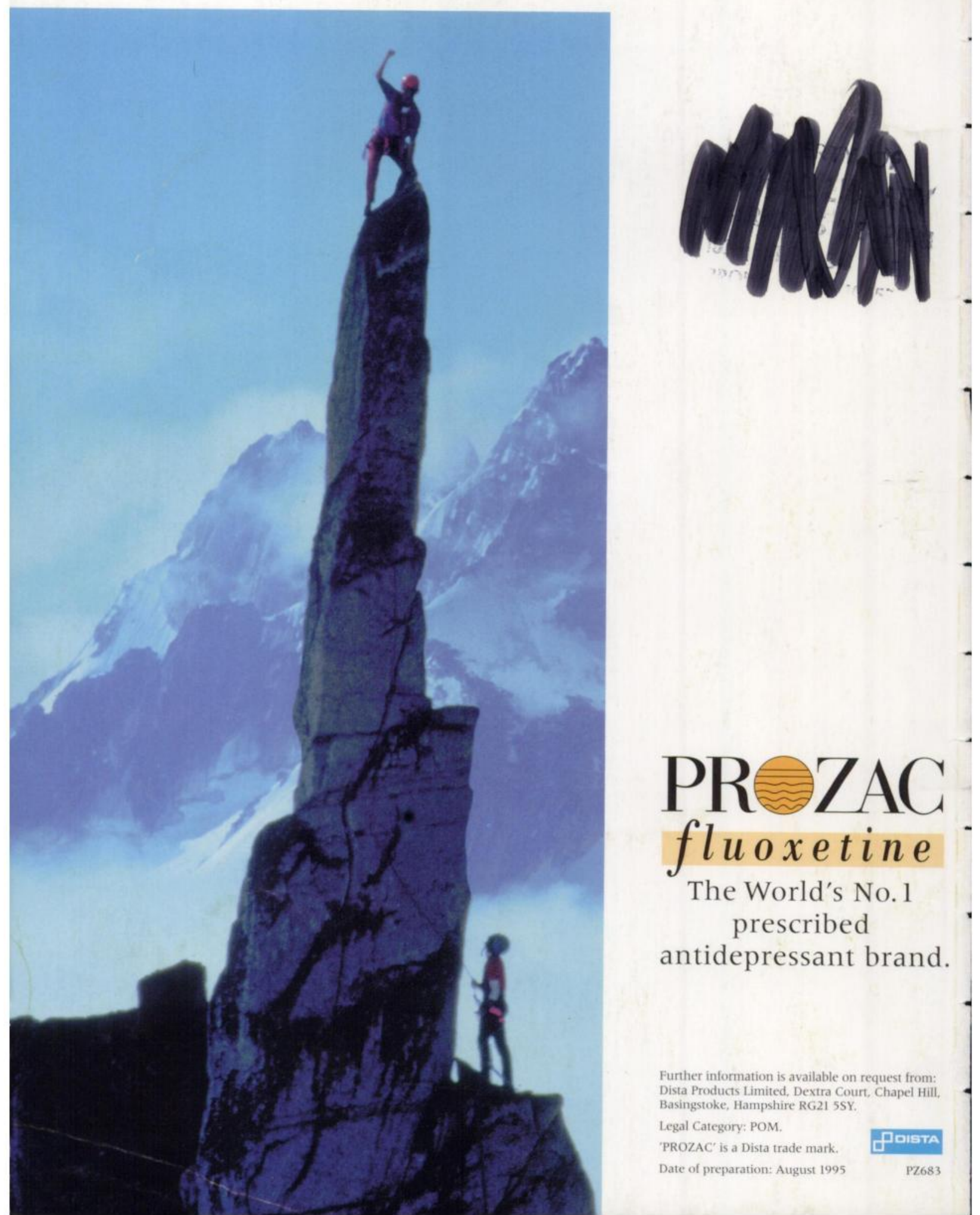

prescribed

antidepressant brand.

Further information is available on request from: Dista Products Limited, Dextra Court, Chapel Hill, Basingstoke, Hampshire RG21 5SY.

Legal Category: POM.

'PROZAC' is a Dista trade mark.

EDIata

Date of preparation: August 1995

PZ683 